\title{
5. DETERMINATION OF THE RELATIONSHIPS OF ELECTRICAL RESISTIVITY, SOUND VELOCITY, AND DENSITY/POROSITY OF SEDIMENT AND ROCK BY LABORATORY TECHNIQUES AND WELL LOGS FROM DEEP SEA DRILLING PROJECT SITES 415 AND 416 OFF THE COAST OF MOROCCO
}

\author{
Robert E. Boyce, Deep Sea Drilling Project, Scripps Institution of Oceanography, La Jolla, California
}

\begin{abstract}
Comparisons of compressional-sound velocity and its relationship to wet-bulk density from well-log data with those of laboratory data, from depths of 113 meters to 273 meters below sea floor in Miocene nannofossil marl and chalk, indicate that the porosities of laboratory samples are about 5 porosity units greater than those of in situ sediments (or on the logs). This is in agreement with predictions by Hamilton (1976) for porosity rebound with the release of overburden pressure. The electrical-resistivity relationship with porosity agrees well with the Archie (1942) type relationship. The models, in decreasing order of agreement are: Boyce (1968), Archie (1942), Kermabon et al. (1969), Winsauer et al. (1952), and Maxwell (1904). In general, acoustic anisotropy increases with age and depth. Anisotropy is typically 0 to 5 per cent (maximum of $14 \%$ ) faster parallel to bedding in Tertiary sediments, from 0 to 661 meters below the sea floor, and typically 0 to 30 per cent in mainly Mesozoic sedimentary rock, from 661 to 1624 meters. Acoustic anisotropy is particularly significant $(0.4 \mathrm{~km} / \mathrm{s}$ or greater) when velocities are from 2.0 to $4.2 \mathrm{~km} / \mathrm{s}$.
\end{abstract}

\section{INTRODUCTION}

This paper is concerned with the physical-property relationships enumerated below, using samples and well logs from Sites 415 and 416, off the coast of Morocco (Figure 1):

1. We will study the electrical formation factor and porosity relationships for soft sediments. These are sparsely reported in the literature yet are essential to the proper interpretation of electric logs;

2. We will undertake one of the first systematic studies of acoustic anisotropy for terrigenous sediments and rocks and its relationship to density and porosity. This information is valuable for the correct interpretation of gravity, seismic-reflection and -refraction, and sonobuoy data;

3. We will test the theory that in situ porosities, for uncemented sediments with significant overburden pressure, are lower than those determined in the laboratory without overburden pressure. This is important where laboratory density and porosity values are used as indexes to other in situ physical properties, sedimentation rates, etc.; and

4. We will also attempt to calculate in situ interval velocities of the geologic section penetrated at Sites 415 and 416 . These values are needed when attempting to correlate the stratigraphic data obtained from the drill holes with seismic profiles.

The comparison of laboratory-measured compressional-sound velocity and wet-bulk density with the ve- locity and density measured in situ from the Schlumberger well logs (see site chapters, this volume) will only be for Hole 415 , as this hole provided the only successful density-log data on Leg 50. The data are from Miocene hemipelagic nannofossil marl and chalk, from depths of 113 meters and 273 meters below the sea floor. The main purpose of this study is to examine the porosity increase or rebound as sedimentary samples are released from the overburden pressure (weight, in sea water, of overlying sediment grains). Porosity rebound has been predicted through laboratory consolidation studies by Laughton (1957) and Hamilton (1959, 1964, 1965, 1976). The data from Leg 50 now offer the opportunity to test these predictions by comparing in situ logging measurements of density and velocity with laboratory measurements.

The relationship of the electrical formation factor (ratio of the electrical resistivity of the sediment to that of the interstitial water) to porosity is significant in the interpretation of the electric well logs in terms of porosity; its investigation is all the more important because only a few published studies of modern marine sediments exist (Boyce, 1968; Kermabon et al., 1969). If the porosities derived from the density and electric logs do not correspond, within the limits of experimental error, the following causes (singly or in combination) are indicated: (1) conductive metallic minerals, (2) anomalies in the salinities of interstitial water, (3) an anomalous temperature, and (4) a large amount of minerals with very high or low grain density. 


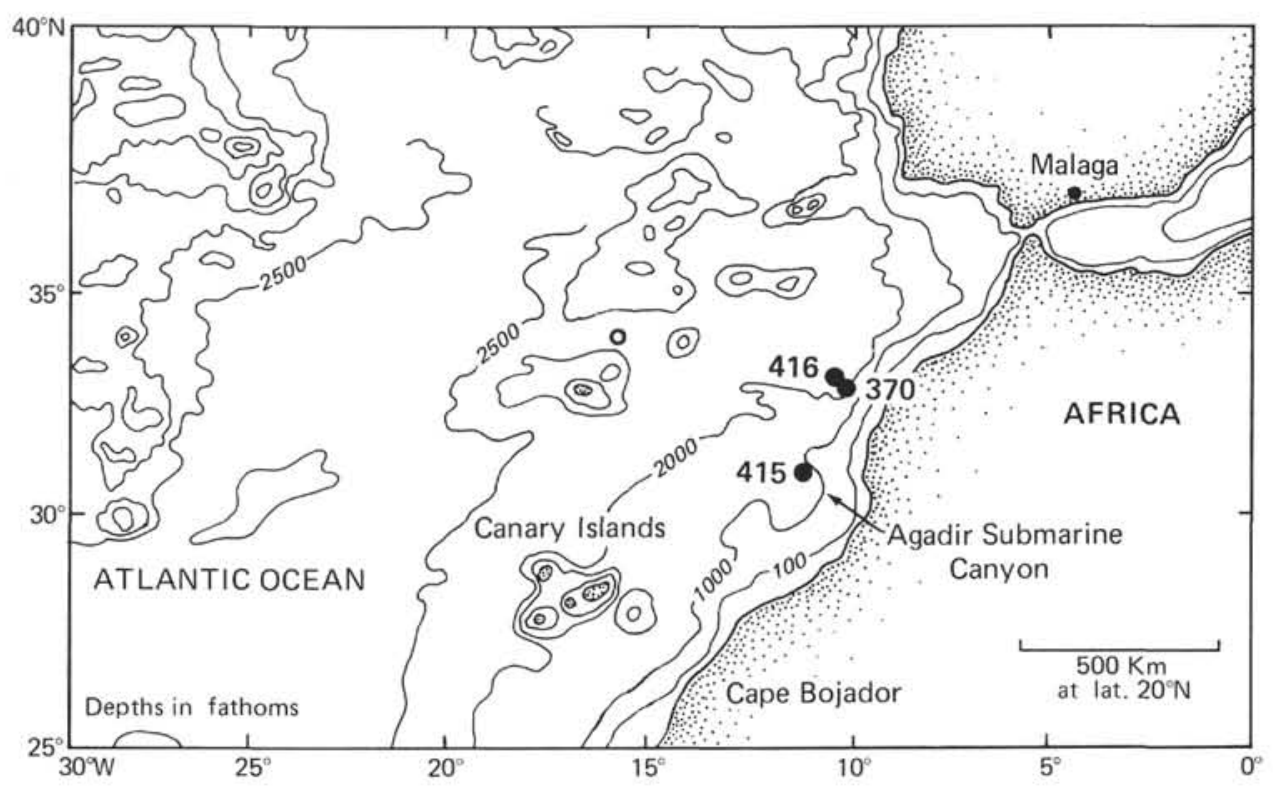

Figure 1. Index map showing locations of DSDP Sites 370, 415, and 416.

The oil companies have mainly studied formation factor-porosity relationships of consolidated sediments or rock, and their empirical formulas (Winsauer et al., 1952; and others) may therefore not be directly applicable to soft, deep-sea sediments. Archie (1942) developed an equation applicable to "clean" sandstone (well sorted, without clay), but it may not accurately predict porosities for sediment incorporating a major fraction of clay-type minerals such as occur in the Leg 50 hemipelagic sediments.

Maxwell's (1904) equation constitutes a theoretical approach for spheres in suspension, which should provide a lower limit of porosity. However, most sediments or rocks are not accurately represented by such a simple model, since they generally have irregularly shaped grains. Conducting ions must therefore travel a longer average path and so will have a greater resistivity and formation factor than those derived from the Maxwell equation for spherical particles.

\section{DATA, DEFINITIONS, AND METHODS}

The sediment classification is discussed in the Explanatory Notes (this volume). Wet-bulk density is defined as the ratio of weight of the water-saturated sediment or rock sample to its volume, expressed as $\mathrm{g} / \mathrm{cm}^{3}$. Water content is the ratio of the weight of sea water in the sample to the weight of the saturated sample, and is expressed as a percentage. Porosity is the ratio of the pore volume in a sample to the volume of the saturated sample, and is also expressed as a percentage. Acoustic impedance is defined as the product of the velocity and wet-bulk density, and is expressed as $\left(\mathrm{g} \cdot 10^{5}\right) /\left(\mathrm{cm}^{2}-\mathrm{s}\right)$. All the equations, derivations, and techniques are discussed in detail in Boyce (this volume).

With respect to sampling, we generally waited at least 4 hours after the core was brought on deck to allow it to reach room temperature. We then cut and removed an undisturbed (visible, undistorted bedding), water-saturated, compressional-sound-velocity sample, about 2.5 $\mathrm{cm}$ thick. The sample was carefully smoothed with a sharp knife or file. Velocities were measured to within \pm 2 per cent accuracy with the Hamilton Frame velocimeter (Boyce, 1976a, and this volume), perpendicular and parallel to bedding. Immediately afterward, its wetbulk density was measured to within \pm 2 or 3 per cent precision with the Gamma Ray Attenuation Porosity Evaluator (GRAPE) (Evans, 1965) as modified in Boyce (1976a, and this volume), using special 2-minute gamma-ray counts. Then, the wet-water content of a subsample was determined by weighing the sample both wet and after drying 24 hours at $110^{\circ} \mathrm{C}$. The weight of evaporated water was corrected for salt $(45 \%)$ to give the weight of sea water (Boyce, 1976a, and this volume; Hamilton, 1971). The estimated precision is \pm 2.5 per cent (absolute). Porosity (precision of $\pm 6 \%$ ) is determined from the product of the wet-water content and wet-bulk density, divided by the density of the interstitial water $\left(1.032 \mathrm{~g} / \mathrm{cm}^{3}\right)$. The acoustic impedance is obtained from the product of the vertical velocity and the wet-bulk density. The laboratory results have been tabulated in the site chapters (this volume).

In situ sound velocity and wet-bulk density were obtained from the Schlumberger Ltd. well logs: Formation Compensated Density (FDC), Bore Hole Compensated Sonic (BHC), and Dual Induction-Laterolog-8 (DIL). They are discussed in Appendix II (Boyce, this volume) and the well-log data in analog form are presented in the site chapters (this volume).

\section{Electrical Resistivity}

The electrical resistivity of any material is defined as the resistance, in ohms, between opposite faces of a unit cube of that material. If the resistance of a conducting 
cube with a length $L$ and cross-sectional area $A$ is $r$, then the resistivity $R_{o}$ is

$$
R_{o}=r A / L=\text { ohm }-\mathrm{m}
$$

Electrical conduction through saturated sediment is complicated by a framework that generally consists of nonconducting mineral grains. If the sediment consists of nonconducting minerals, the electrical conduction is primarily through the interstitial water, whose conductivity varies with temperature, pressure, and salinity (Horne, 1965; Horne and Courant, 1964; Horne and Frysinger, 1963; Thomas et al., 1934). However, conduction through the fluid can be modified significantly if metallic minerals are present with appreciable conductivity, or clay-type minerals that exchange or withdraw ions from the interstitial water (de Witte, 1950a,b; Patnode and Wyllie, 1950; Keller, 1951; Berg, 1952; Winsauer and McCardell, 1953; Wyllie, 1955). Charged colloidal particles and exchanged ions are not necessarily removed from the sediment when the interstitial water is sampled; therefore, they do not contribute to what is normally thought of as the water salinity (Keller, 1951; Howell, 1953).

The formation factor, $F$, is the ratio of electrical resistivity of the saturated sediment, $R_{o}$, to the resistivity of the interstitial water, $R_{w}$, at the same temperature and pressure (Archie, 1942):

$$
F=R_{o} / R_{w}
$$

The formation factor has been related to porosity and fluid salinity of rocks or sediments by Archie (1942, 1947), Winsauer et al. (1952), and others (Table 1). Where the mineral composition of the sediment forms a nonconductive matrix and the interstitial water conductivity is high, $F$ is considered to be the "true" formation factor, which, with increasing salinity of the interstitial water, approaches a constant value for a given porosity and rock sample (Patnode and Wyllie, 1950; Keller and Frischkecht, 1966).

Where, on the other hand, sediments contain minerals that are conductors, this ratio is considered to be an "apparent" formation factor, and is lower than the "true" formation factor of sediments, for a given set of porosity, textural, and cementation characteristics. The "apparent" formation factor approaches a constant value with different salinities, at a given porosity, only if the conductivity of the interstitial water is much greater than that of the conducting minerals (Berg, 1952; Howell, 1953; Wyllie and Southwick, 1954; Wyllie, 1955).

The variation of apparent formation factor with interstitial-water resistivity may be in part related to the distribution of conducting grains in a sample. Wyllie and Southwick (1954) developed a model showing that the connected conducting grains are conductors in parallel and isolated conducting grains are conductors in series with the interstitial fluid. If the interstitial fluid is a good conductor, all the conducting grains contribute to the overall conduction of the rock matrix. If the in-
TABLE 1

Electrical Formation Factor - Porosity Relations ${ }^{\mathrm{a}}$ of Water-Saturated Sedimentary Rock and Sediment

Maxwell (1904) theoretically derived the following relationship for a suspension of spheres:

$$
F=\frac{3-\phi}{2 \phi}
$$

where,

$F=R_{O} / R_{W}=$ formation factor, in which

$R_{O}=$ the electrical resistivity of the saturated formation;

$R_{w}=$ the resistivity of the interstitial water;

$\phi^{W}=$ the porosity expressed as a fraction or decimal.

Archie's (1942) equation was derived for consolidated sandstone without clay material:

$$
F=\phi^{-m}=\phi^{-2}
$$

where $m$ is a variable depending on consolidation, texture, and cementation.

Winsauer et al. (1952) derived a slightly different empirical formula for various sandstone formations:

$$
F=a \phi^{-m}=0.62 \theta^{-2.15}
$$

where $a$ and $m$ are variables depending on cementation, textures, and mineralogy of the formation.

Boyce (1968) derived the following empirical equation for modern marine diatomaceous silty clay to silty sand (this equation is of the same form as Winsauer et al., 1952):

$$
F=1.30 \theta^{-1.45}
$$

Kermabon et al. (1969) derived the following empirical equation (one of three) also for modern marine clays and turbidite sands:

$$
F=\left(\frac{1.45}{\phi}\right)^{1.46}-0.719
$$

${ }^{a}$ Keller (1966) and Keller and Frischknecht (1966) summarize and discuss similar equations derived for continental formations.

terstitial fluid is a moderate or poor conductor, the conducting grains in series with the interstitial water will make a reduced contribution to the overall conduction of the rock matrix. Thus, the formation factor increases resistivity of the fluid.

Clay-type minerals with varying exchange capacities and other possible conducting minerals may act as resistors or conductors relative to different interstitial-water resistivities, and so the formation factor (for a given sample) may not be constant for different interstitialwater resistivities (Keller, 1951; Wyllie, 1955; Berg, 1952; Wyllie and Gregory, 1953; Winsauer et al., 1952; Winsauer and McCardell, 1953; Wyllie and Southwick, 1954; Keller and Frischknecht, 1966).

The resistivity of interstitial water may be estimated by measuring the water squeezed from the sample, or by assuming it to be equal to that of sea water. However, interstitial-water sampling may not remove ions that are filtered or trapped by clay-type minerals (Scholl, 1963). In addition, the natural sediment compaction from 
overburden pressure may trap or filter various ions as the fluid migrates. Thus the interstitial fluid may have a different chemical composition from that of the original interstitial sea water (Siever et al. 1961; Siever et al., 1965). Therefore, the electrical resistivity of the interstitial water determined, for example, by using data of Thomas et al. (1934) may be in error, because these investigators assumed a chemical composition like that of seawater.

Fresh sediment may be anisotropic with respect to electrical resistivity (Bedcher, 1965), but consolidated sediments and rock are anisotropic. Resistivity parallel to bedding is typically lower than that perpendicular to bedding (Keller, 1966; Keller and Frischknecht, 1966).

The shapes of the individual mineral grains also play a part: the more angular grains create a greater path length through the sediment and thus a higher resistivity and higher formation factor for a given porosity (Wyllie and Gregory, 1953). The resistivity is further affected by grain-size distribution, particularly for clay-type minerals. A lesser grain size gives a greater surface area with an ion-exchange capacity and thus increases the number of ionic-cloud conductors in a given sample. To a lesser extent this is also true of non-clay-type minerals, such as quartz and feldspar (Keller and Frischknecht, 1966).

\section{Sound Velocity}

Compressional-sound velocity in isotropic material has been defined (Wood, 1941; Bullen, 1947; Birch, 1961; Hamilton, 1970) as:

$$
V=\left(\frac{k+\frac{4 \mu}{3}}{\rho_{b}}\right)^{1 / 2}
$$

where $V$ is the compressional velocity,

$\rho_{b}$ is the wet-bulk density in $\mathrm{g} / \mathrm{cm}^{3}$, where $\rho_{b}=\rho_{w} \phi+(1-\phi) \rho_{g}$, in which $\phi$ is the fractional porosity of the sediment or rock and the subscripts $b, g$, and $w$, represent the wet-bulk density, grain density, and water density, respectively,

$k$ is the incompressibility or bulk modulus, and

$\mu$ is the shear (rigidity) modulus.

Where samples are anisotropic, $k$ and $\mu$ may have unique values for the corresponding vertical and horizontal directions. See Laughton (1957) for discussions of anisotropy.

Compressional velocity of sediments and rocks has been related to the sediment components by Wood (1941), Wyllie et al. (1956), and Nafe and Drake (1957), whose equations are listed in Table 2 and will be discussed later. Velocity is related to mineralogical composition, fluid content, temperature, pressure, grain size, texture, cementation, direction with respect to bedding or foliation, and alteration, as summarized in Press (1966).
TABLE 2

Theoretical Equations Relating Compressional Velocity of the Water-Saturated Rock to the Velocities and Densities of the Fluid and Solid-Grain End-Member Constituents

Wood $^{\mathrm{a}}$ (1941) equation applies to velocities through suspensions without rigidity:

$$
V_{b}=\left(\frac{1}{\left[\phi \beta_{w}+(1-\phi) \beta_{g}\right]\left[\phi \rho_{w}+(1-\phi) \rho_{g}\right]}\right)^{1 / 2}
$$

where:

$$
\begin{aligned}
V= & \text { compressional velocity; } \\
\rho= & \text { density, } \beta=\text { compressibility, and subscripts } g, w, \text { and } b \\
& \text { represent the solid grains, interstitial water, and wet-bulk } \\
& \text { rock or sediment, respectively; } \\
\phi= & \text { fractional porosity where } \rho_{b}=\phi \rho_{w}+(1-\phi) \rho_{g} .
\end{aligned}
$$

Wyllie et al. ${ }^{\mathrm{a}}$ (1956) equation applies in rocks with rigidity:

$$
\frac{1}{V_{b}}=\frac{\phi}{V_{w}}+\frac{(1-\phi)}{V_{g}}
$$

Nafe and Drake (1957) equation applies to rock with varying degrees of rigidity, which is controlled in the equation by the value of $n$ :

$$
V_{b}^{2}=\phi V^{2}\left[1+\left(\frac{\rho_{w}}{\rho_{b}}\right)(1-\phi)\right]+\frac{\rho_{g}}{\rho_{b}}(1-\phi)^{n} V_{g}{ }^{2}
$$

Boyce (1976b) equation allows laboratory velocities to be corrected for hydrostatic pressure and temperature:

$$
V_{I I I}=\left[\frac{\left(V_{3}-V_{2}\right)\left(V_{I}-V_{I I}\right)}{\left(V_{1}-V_{2}\right)}\right]+V_{I I}
$$

where

$V_{1}=$ Velocity of pore water at laboratory conditions;

$V_{2}=$ Velocity of calcite (or other minerals) end-member at laboratory conditions;

$V_{3}=$ Velocity of sample at laboratory conditions;

$V_{I}^{3}=$ Velocity of pore water at in situ temperature and hydrostatic pressure;

$V_{I I}=$ Velocity of calcite (or other mineral[s] end-member) at in situ temperature and hydrostatic pressure;

$V_{I I I}=$ Velocity of sample at in situ temperature and hydrostatic pressure.

${ }^{\text {a }}$ The Wood (1941) equation and Wyllie et al. (1965) equations theoretically would be the lower and upper limits to the velocityporosity relationship in isotopic samples. The Wyllie et al, (1956) equation assumes an average velocity of slab of solid mineral in proportion to the rocks porosity (e.g., $60 \%$ porosity calcite would be equivalent to the average velocity of a slab of water $60 \mathrm{~m}$ thick and slab of completely rigid calcite $40 \mathrm{~m}$ thick).

In situ velocities will be estimated from the laboratory data by using techniques as in Boyce (1976b). These methods will also be discussed later.

\section{RESULTS}

\section{Scatter Diagrams}

The following scatter diagrams are presented to provide empirical relationships, to compare with previous studies, and to help develop predictive relationships. 
The first group of scatter diagrams (Figures 2 and 3 ) are laboratory-determined (GRAPE 2-minute count) wet-bulk densities versus laboratory-determined porosities. The data are from Cenozoic marl and chalk and Cretaceous to Tithonian sandstone and siltstone turbidites in mudstone and minor limestone, from 0 to 1624 meters below the sea floor at Sites 415 and 416. In these diagrams, the grain density of each sample may be estimated by a line from " $1.032 \mathrm{~g} / \mathrm{cm}^{3}$ (for $45 \%$ median salinity) density at 100 per cent porosity" through "the given datum point" to the " 0 per cent porosity axis." The grain density is the bulk-density value at 0 per cent porosity. This grain-density determination is subject to great uncertainty, especially at high porosity, but it at least permits identification of sample data of doubtful accuracy. Unusual grain-density values could be the result of laboratory mistakes or gas in the samples.

The next scatter diagram plots the formation factor, $F$, versus porosity, $\phi$, expressed as a fraction (Figure 4 ). This diagram includes the well-logging data from Site 415 (open circles) and the laboratory data of modern surficial sediments from the Bering Sea (Boyce, 1968) (the black solid dots). The Schlumberger well-log and associated data are listed in Table 3. These data are from Miocene hemipelagic nannofossil marl and chalk from 115 to 273 meters below the sea floor at Site 415 . The in situ salinities were estimations based on interpolations between a few salinity measurements on Legs 41 (Couture et al., 1978) and 50 (Gieskes et al., this volume). In situ resistivities of the interstitial water were calculated using the Thomas et al. (1934) resistivitysalinity-temperature chart. These resistivity values were then corrected by hydrostatic pressure, using equations of Horne and Frysinger (1963). The well-log formation resistivity, $R_{0}$, was calculated using corrections in Schlumberger (1972) Log Interpretation Charts and assuming a hole diameter of 12 inches $(30 \mathrm{~cm})$.

The formation factor, $F$, was calculated from estimates of $R_{w}$ and $R_{o}$ from the logs at 10-meter intervals. $F$ was plotted against the wet-bulk density from the FDC log, also measured at 10-meter intervals, using the associated gamma-ray logs to be certain the same lithological interval is used as for the electric logs. The wetbulk density from the FDC was completely corrected using the Schlumberger (1972) Log Interpretation Charts, assuming a 12 -inch $(30-\mathrm{cm})$ hole diameter, and the porosity was calculated assuming a $2.7-\mathrm{g} / \mathrm{cm}^{3}$ grain density and a $1.032-\mathrm{g} / \mathrm{cm}^{3}$ water density (typical density). When salinity became greater than 40.9 per mill, the $R$ calculations were discontinued, as the Thomas et al. (1934) charts ended at 41 per mill salinity. It may have been possible to extrapolate the Thomas data or use the sodium-chloride salinity charts from the Schlumberger manual, but we did not want to introduce any additional uncertainties into the scatter diagrams of $F$ versus porosity.

Also displayed in Figure 4 are various porosityformation factor relationships developed by Maxwell (1904) (isotropic material), Archie (1942) (perpendicular[?] to bedding), Winsauer et al. (1952) (parallel to

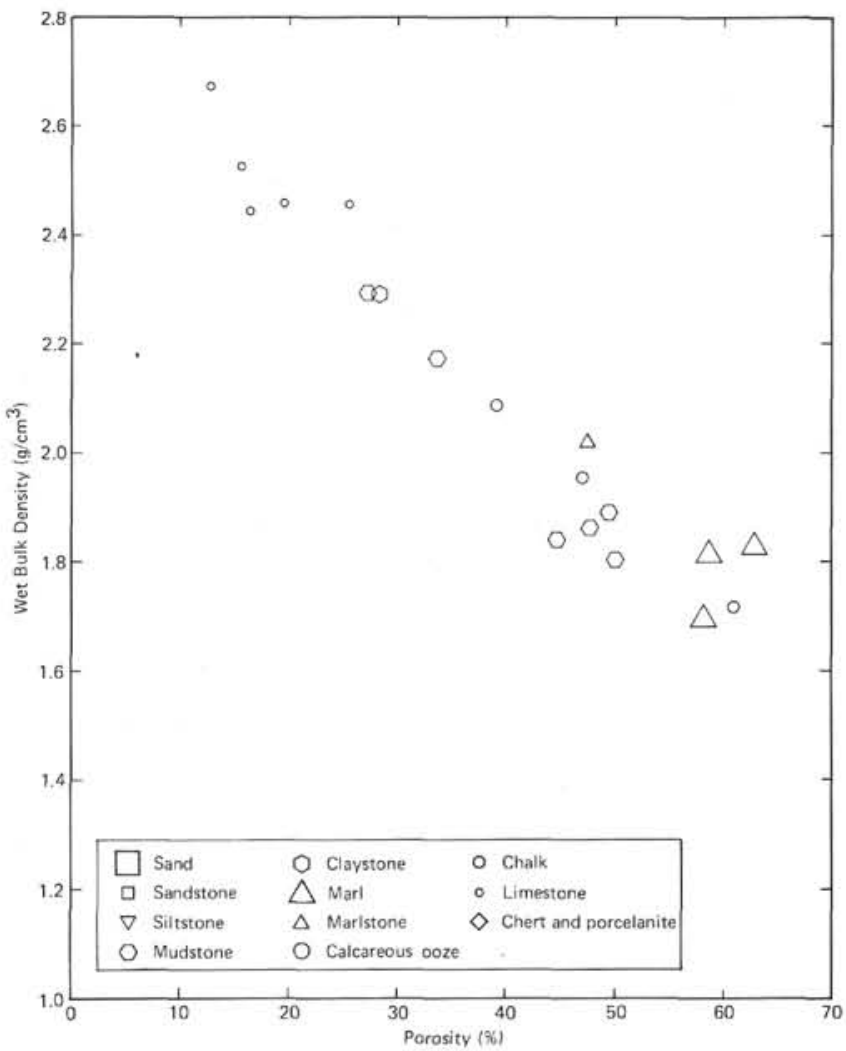

Figure 2. Wet-bulk density versus porosity as determined in the laboratory on cores from Site 415.

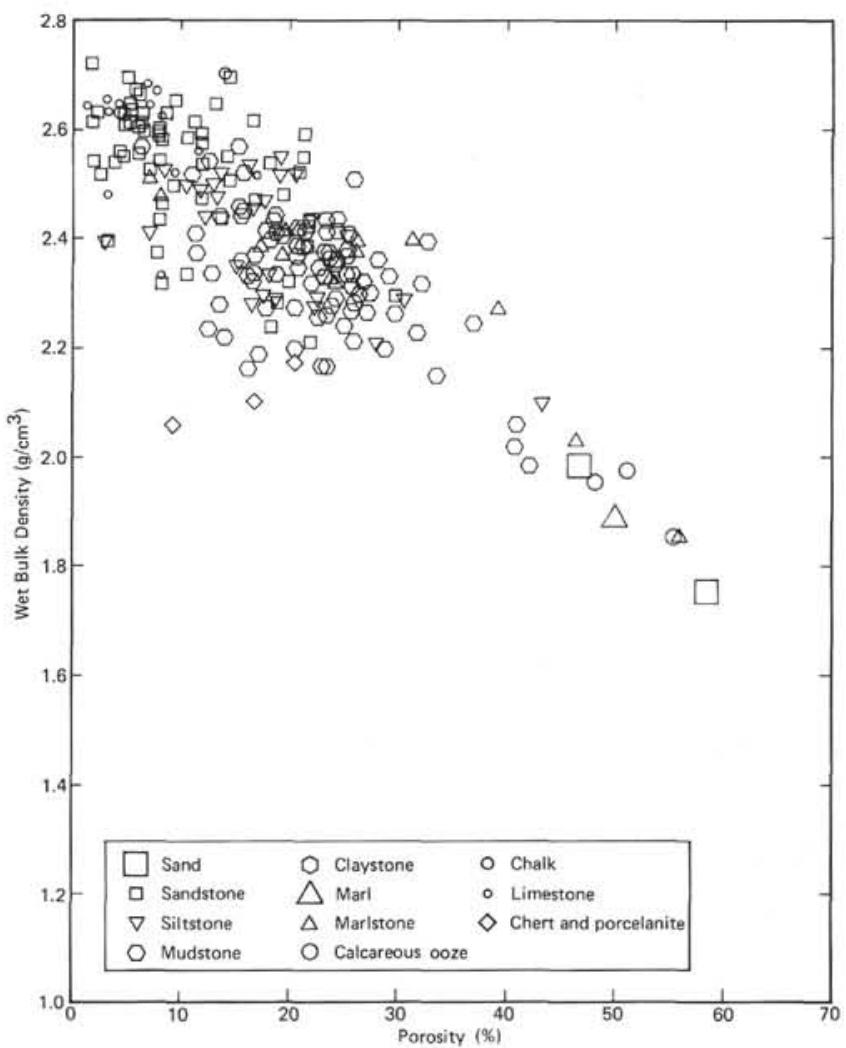

Figure 3. Wet-bulk density versus porosity as determined in the laboratory on cores from Site 416. 


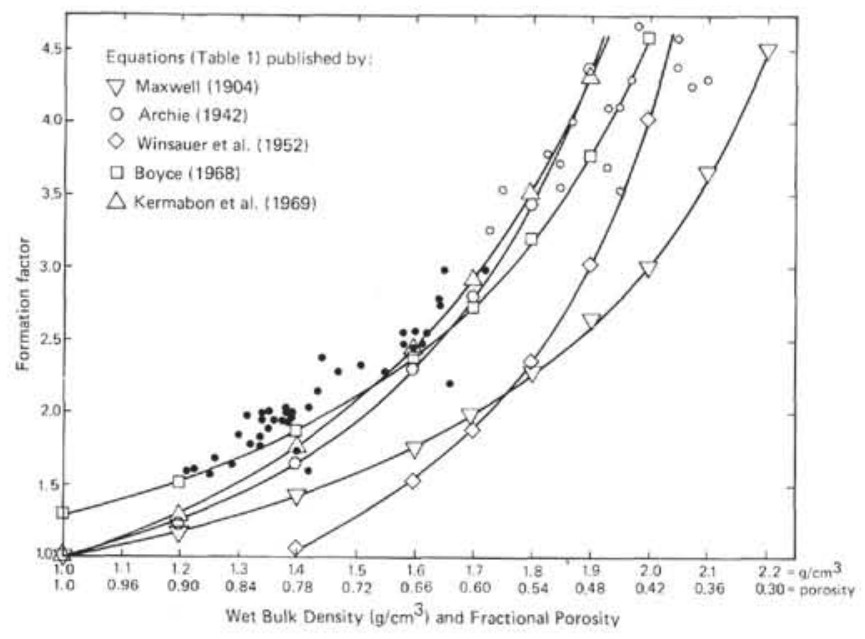

Figure 4. Electrical "formation factor" (horizontal) versus density/porosity. The solid data points are from laboratory studies of modern marine sediments by Boyce (1968). The open circles are the Site 415 Schlumberger well-log resistivity and density data (the porosity is calculated from the wet-bulk density by assuming a grain density of $\left.2.7 \mathrm{~g} / \mathrm{cm}^{3}\right)$. Equations relating the formation factor and porosity by other investigators are coded and these equations are presented in Table 1. bedding), Boyce (1968) (perpendicular to bedding, but the surface samples may be isotropic), and Kermabon et al. (1969) (perpendicular to bedding, but the surface samples may be isotropic). Other equations are summarized in Keller and Frischknect (1966). The formation factors were calculated for different salinities (37 to $41 \% 0$ ), temperatures, hydrostatic pressures, and for sediments containing varying amounts of clay minerals; therefore, the formation factor may not necessarily be a constant for a given set of porosity, textural, and cementation characteristics. Thus, a least-squares solutions through $\log$-derived $F$ and $\phi$ values would probably not be appropriate. In addition, the well- $\log R_{o}$ is in a direction parallel to bedding, which is usually less than the $R_{o}$ perpendicular to bedding (Keller and Frischknecht, 1966).

The Boyce (1968) data are plotted in Figure 4, in order that the precision of laboratory data may be compared with that of the logging data. In general, the welllog data agree with the following equations, in decreasing order of agreement: Boyce (1968), Archie (1942), Kermabon et al. (1969), Winsauer et al. (1952), and Maxwell (1904). Although the Boyce (1968) data for high-porosity sediments and the Schlumberger data for medium-porosity sediments agree well, one cannot conclude that data for high-porosity sediments at this site, if available, would give similar agreement.

TABLE 3

Electrical Resistivity, Formation Factors, Sound Velocity, and Wet-Bulk-Density Data From the Well Logs and Other Associated Data, Site 415

\begin{tabular}{|c|c|c|c|c|c|c|c|c|c|}
\hline $\begin{array}{c}\text { Depth Belowa } \\
\text { Sea Level } \\
\text { (m) }\end{array}$ & $\begin{array}{c}\text { Temperature }{ }^{\mathrm{a}} \\
\left({ }^{\circ} \mathrm{C}\right)\end{array}$ & $\begin{array}{c}\text { Interstitial }^{b} \\
\text { Water } \\
\text { Salinity } \\
(\% \circ)\end{array}$ & $\begin{array}{c}\text { Hydrostatic } \\
\text { Pressure } \\
\left(\mathrm{kg} / \mathrm{cm}^{2}\right)\end{array}$ & $\begin{array}{l}\text { Electrical }^{\mathrm{d}} \\
\text { Resistivity } \\
\text { of Interstitial } \\
\text { Water, } R_{w} \\
\text { (ohm-m) }\end{array}$ & $\begin{array}{l}\text { Formation } \\
\text { Resistivity, } R_{O} \\
\quad(\text { ohm-m) }\end{array}$ & $\begin{array}{c}\text { Formation } \\
\text { Factor } \\
R_{O} / R_{W}\end{array}$ & $\begin{array}{c}\text { FDC } \\
\text { Wet Bulk } \\
\text { Density } \\
\left(\mathrm{g} / \mathrm{cm}^{3}\right)\end{array}$ & $\begin{array}{c}\text { Porosity } \\
\text { (fractional) }\end{array}$ & $\begin{array}{c}\text { BHC } \\
\text { Sonic } \\
\text { Velocity } \\
(\mathrm{km} / \mathrm{s})\end{array}$ \\
\hline 2920 & 6.78 & 37.4 & 302 & 0.257 & 0.91 & 3.54 & 1.75 & 0.57 & 1.64 \\
\hline 2930 & 7.08 & 37.6 & 303 & 0.253 & 0.94 & 3.72 & 1.85 & 0.51 & 1.58 \\
\hline 2940 & 7.38 & 37.8 & 304 & 0.252 & 1.01 & 4.01 & 1.87 & 0.50 & 1.64 \\
\hline 2950 & 7.68 & 38.0 & 305 & 0.248 & 1.02 & 4.11 & 1.93 & 0.46 & 1.68 \\
\hline 2960 & 7.98 & 38.1 & 306 & 0.246 & 0.91 & 3.70 & 1.93 & 0.46 & 1.64 \\
\hline 2970 & 8.23 & 38.3 & 307 & 0.243 & 1.00 & 4.12 & 1.95 & 0.45 & 1.74 \\
\hline 2980 & 8.58 & 38.4 & 308 & 0.240 & 1.03 & 4.30 & 1.97 & 0.44 & 1.76 \\
\hline 2990 & 8.88 & 38.6 & 309 & 0.237 & 1.04 & 4.39 & 2.05 & 0.39 & 1.84 \\
\hline 3000 & 8.94 & 38.6 & 311 & 0.237 & 1.02 & 4.30 & 2.10 & 0.36 & 2.01 \\
\hline 3010 & 9.18 & 38.7 & 312 & 0.235 & 1.00 & 4.26 & 2.07 & 0.38 & 1.84 \\
\hline 3020 & 9.48 & 38.9 & 313 & 0.233 & 1.07 & 4.59 & 2.05 & 0.39 & 2.10 \\
\hline 3030 & 9.78 & 39.2 & 314 & 0.229 & 0.81 & 3.54 & 1.95 & 0.45 & 1.92 \\
\hline 3040 & 10.08 & 39.5 & 315 & 0.225 & 0.80 & 3.56 & 1.85 & 0.51 & 1.58 \\
\hline 3050 & 10.38 & 39.8 & 313 & 0.223 & 0.84 & 3.79 & 1.83 & 0.52 & 1.64 \\
\hline 3060 & 10.68 & 40.0 & 317 & 0.221 & 0.72 & 3.26 & 1.73 & 0.58 & 1.64 \\
\hline 3070 & 10.98 & 40.4 & 318 & 0.219 & 1.01 & 4.61 & - & - & - \\
\hline 3080 & 11.28 & 40.6 & 319 & 0.216 & 1.01 & 4.68 & 1.98 & 0.43 & 1.91 \\
\hline
\end{tabular}

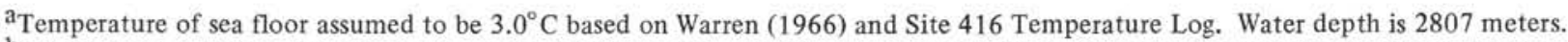

${ }^{b}$ Salinity of interstitial water from linear interpolation between shipboard determinations. Sea floor is assumed to be $35 \%$ based on Fairbridge et al. (1966).

The hydrostatic pressure is calculated as $=($ depth below sea level $) \times\left(1.035 \mathrm{~g} / \mathrm{cm}^{3}\right)$.

dElectrical resistivity is calculated from the temperature and salinity based on Thomas et al. (1934) and the corrected for hydrostatic pressure by Horne and Frysinger (1963) techniques.

e Porosity $=\frac{\rho_{\mathrm{g}}-\rho_{\mathrm{b}}}{\rho_{\mathrm{g}}-\rho_{\mathrm{w}}}$, when $\rho_{\mathrm{g}}=2.70, \rho_{\mathrm{w}}=1.03 \mathrm{~g} / \mathrm{cm}^{3}$, and $\rho_{\mathrm{b}}$ from FDC log. 
The primary importance of Figure 4 is to demonstrate the relationship of the Schlumberger logging data to various $F$ - $\phi$ equations, so that the latter may be used in determining the porosity from the electric-log data, and in estimating the accuracy of the results.

Figure 5 displays the formation factor versus velocity from the Schlumberger logs from Sites 415 and 416, for Cenozoic hemipelagic nannofossil marl and chalk from 100 to 450 meters below the sea floor at Sites 415 and 416. There is no precise relationship for these highporosity sediments in which the sound velocity does not vary greatly with porosity, but $F$ does have a distinct relationship to porosity. In addition, $R_{o}$ is parallel to bedding, which is usually less than $R_{\mathrm{o}}$ normal to bedding (Keller and Frischknecht, 1966), while the velocity is perpendicular to bedding, which is normally less than that parallel to the bedding. (See Table 3 and 4.)

Acoustic anisotropy is important for estimating vertical velocities (for seismic-reflection profiles) from the horizontal velocities determined by refraction techniques, and the oblique velocities determined by sonobuoy techniques.

Acoustic anisotropy in sedimentary rock may be created by some combination of the following variables as summarized in Press (1966): (1) alternating layers with high- or low-velocity materials; (2) tabular minerals that are aligned with bedding, thus creating fewer gaps in a direction parallel to bedding; (3) the presence of minerals with acoustic anisotropy, whose highvelocity axis may be aligned with the bedding plane; and (4) foliation parallel to bedding.

Figure 6 shows acoustic anisotropy for Cenozoic hemipelagic nannofossil marls and chalk, from 0 to $661 \mathrm{me-}$ ters below the sea floor, and mainly Cretaceous to Tithonian sandstone and siltstone turbidites in mudstone and minor limestone from 661 to 1624 meters below the sea floor. In general, the anisotropy is small $(0-5 \%$ is typical, with a maximum of $15 \%$ ) for Cenozoic hemipelagic sediments with velocities less than about $2 \mathrm{~km} / \mathrm{s}$. Acoustic anisotropy of the Cretaceos-Jurassic sedimentary rocks, which have velocities between about 2.0 and $4.2 \mathrm{~km} / \mathrm{s}$, is about $0.4 \mathrm{~km} / \mathrm{s}$, more in the horizontal than in the vertical plane. Some samples have an absolute anisotropy as great as $1.0 \mathrm{~km} / \mathrm{s}$. The relative acoustic anisotropy ranges from 0 to 30 per cent, 5 to 20 per cent being typical. The mudstones, which have velocities of 2.0 to $3.0 \mathrm{~km} / \mathrm{s}$, tend to have the greatest anisotropy, as compared with the higher-velocity ( 3 to $4.2 \mathrm{~km} / \mathrm{s}$ ) sandstones, siltstones, and limestones. Where the sandstone, siltstone, and limestone have velocities greater than about $4.2 \mathrm{~km} / \mathrm{s}$, the acoustic anisotropy becomes much less significant, as the sample is more thoroughly cemented.

Based on data from the Cenozoic to Tithonian sediments and rocks at Sites 415 and 416 , the scatter diagrams of horizontal and vertical velocity versus wettheoretical equations (listed in Table 2), which utilized here for simplicity a calcium-carbonate matrix $(6.45$ $\left.\mathrm{km} / \mathrm{s} ; 2.72 \mathrm{~g} / \mathrm{cm}^{3}\right)$ saturated with sea water $(1.53 \mathrm{~km} / \mathrm{s}$; $\left.1.025 \mathrm{~g} / \mathrm{cm}^{3}\right)$. Wood's (1941) equation assumes a sus-

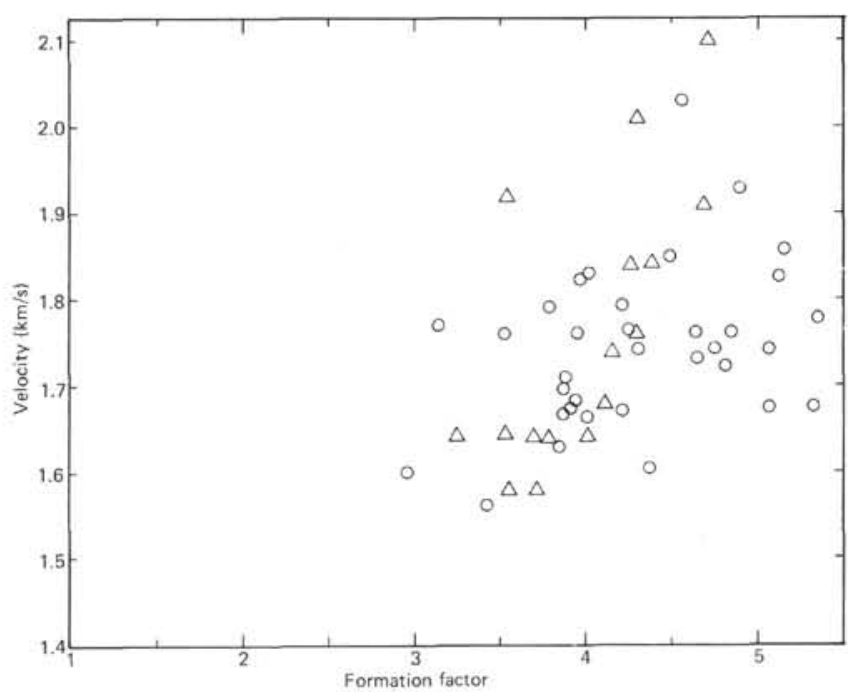

Figure 5. Vertical velocity versus (horizontal) electrical formation factor for Site 415 (triangles) and Site 416 (circles) from the well-log data.

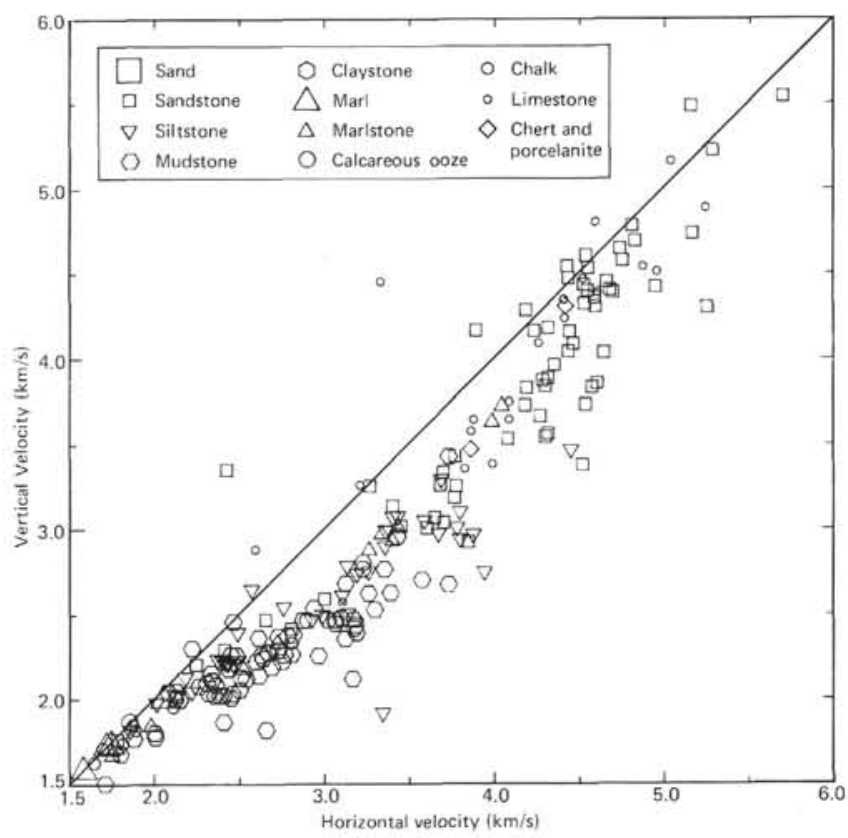

Figure 6. Laboratory horizontal velocity versus laboratory vertical velocity, which are coded for lithological type. Data are from Sites 415 and 416.

bulk density (Figure 7) and porosity (Figure 8) represent one of the first systematic studies of terrigenous sediments to introduce anisotropy into these relationships. The latter are important for the interpretation of gravity and seismic data in terms of subsurface structures and for well-log analysts who may be required to estimate porosity from a sonic log.

The average of the horizontal and vertical velocity is plotted against wet-bulk density and porosity in Figures 9 and 10, respectively. These figures illustrate the Wood (1941), Wyllie et al. (1956), and Nafe and Drake (1957) 


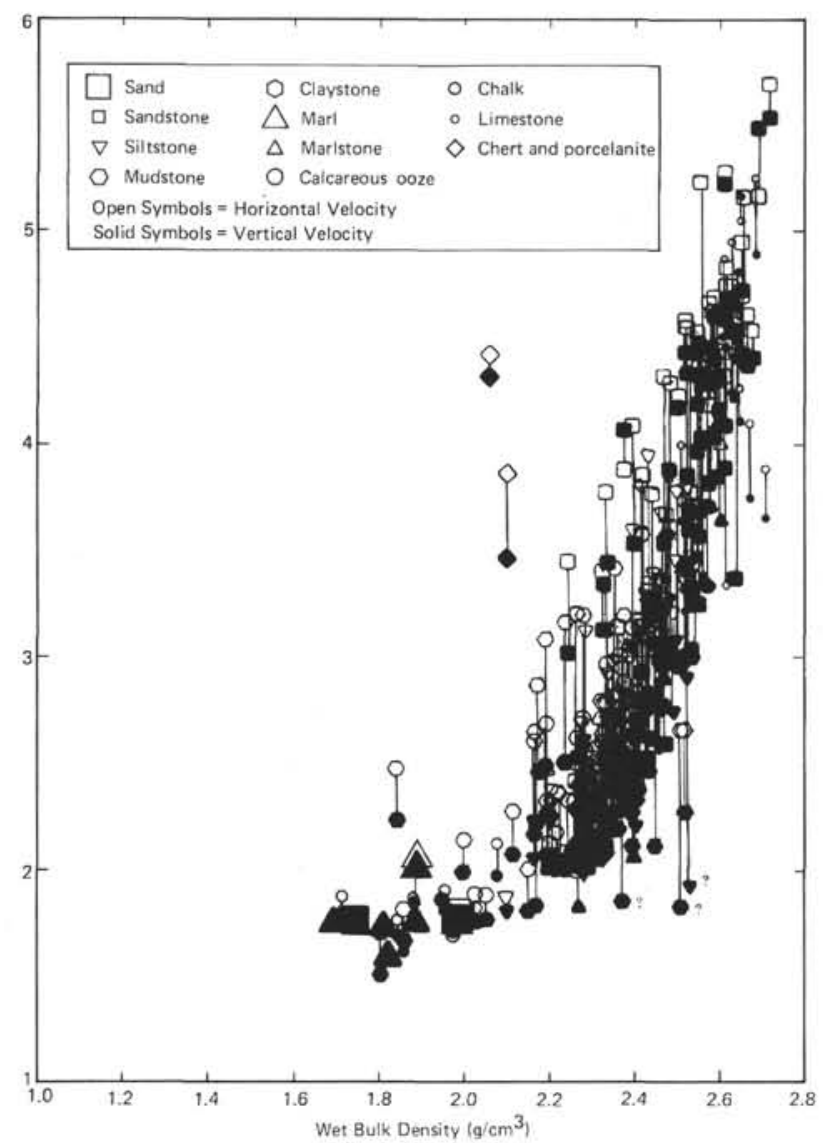

Figure 7. Laboratory horizontal and vertical velocities versus laboratory wet-bulk density, from Sites 415 and 416.

theoretical equations (listed in Table 2), which utilize here for simplicity a calcium-carbonate matrix $(6.45$ $\left.\mathrm{km} / \mathrm{s} ; 2.72 \mathrm{~g} / \mathrm{cm}^{3}\right)$ saturated with sea water $(1.53 \mathrm{~km} / \mathrm{s}$; $1.025 \mathrm{~g} / \mathrm{cm}^{3}$ ). Wood's (1941) equation assumes a suspension of spheres without rigidity and theoretically applies best to soft, unconsolidated sediment. This equation would tend to be the lower velocity limit. The Wyllie et al. (1956) equation assumes (1) complete rigidity of the carbonate matrix and (2) that the model is similar to sound traveling perpendicularly through a solid slab of calcite and slab of water. The ratio of the thicknesses of the water and the calcite slabs is the same proportion as the porosity of the sample. This equation should theoretically be the upper velocity limit. The Nafe and Drake equation is shown for $n$ values of 4,6 , and 9 . No single value of $n$ fits all the data. For some of its values, the Nafe and Drake (1957) equation velocities may be too high (greater than those from the Wyllie et al. equation), or too low (lower than those from the Wood equation).

Acoustic impedance versus vertical velocity is plotted in Figure 11 for the Cenozoic to Tithonian sediments and rocks from Sites 415 and 416 and approximates a linear relationship. Normally the plot segregates different mineralogies into separate lines representing different bulk elasticity for rock types such as basalt, clastics, limestone, and chert (Boyce, 1976b). However, in Figure 11, a single line is developed for Leg 50 clastic sedi-

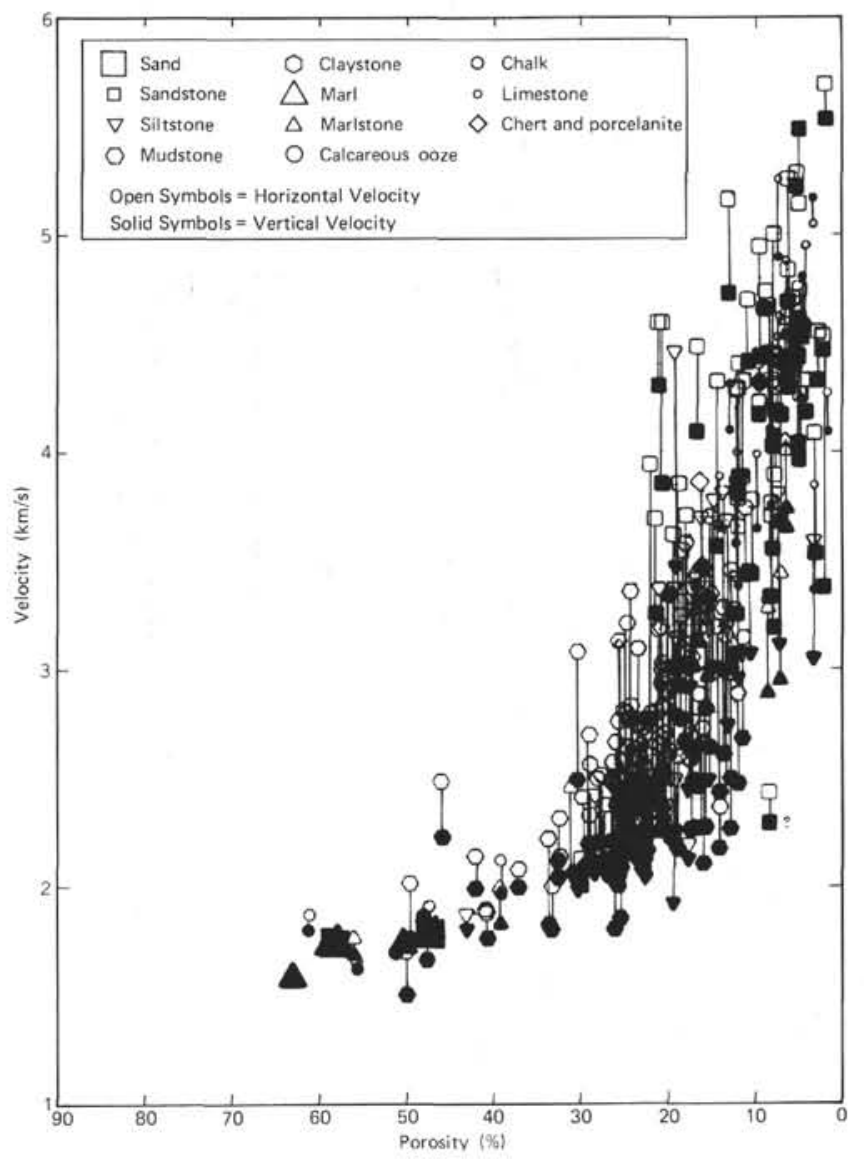

Figure 8. Laboratory-determined horizontal and vertical velocity versus porosity, from Sites 415 and 416.

ments, sedimentary rock, and limestone. Different mineralogies do not display different lines for carbonates and terrigenous clastics, as in Boyce (1976b), because the quartz-feldspar-clay clastics are cemented by calcite.

\section{Comparison of Laboratory Velocity/Density to In Situ Velocity/Density}

In attempting to calculate in situ velocities from labotory velocities, it is important to correct the latter for the porosity rebound a sample undergoes when it is removed from deep within the sea floor, thereby releasing the overburden pressure (as discussed by Hamilton, 1965, 1976). According to Hamilton (1976), it amounts to up to 8 per cent porosity units, depending on the lithology of the laboratory-uncemented sample and on the depth at which the sample was buried below the sea floor.

Leg 50 laboratory data and well-logging data offer an opportunity to make a very cursory study of this problem, albeit for only a very limited range of conditions and only at Site 415 , which is the only site of Leg 50 where the density log was successful. At this site we obtained good Schlumberger logs for wet-bulk density and velocity in Miocene hemipelagic sediments from 113 to 273 meters below the sea floor. A serious limitation is that we only had three cores in this depth interval for comparison with the logging (Table 4). 


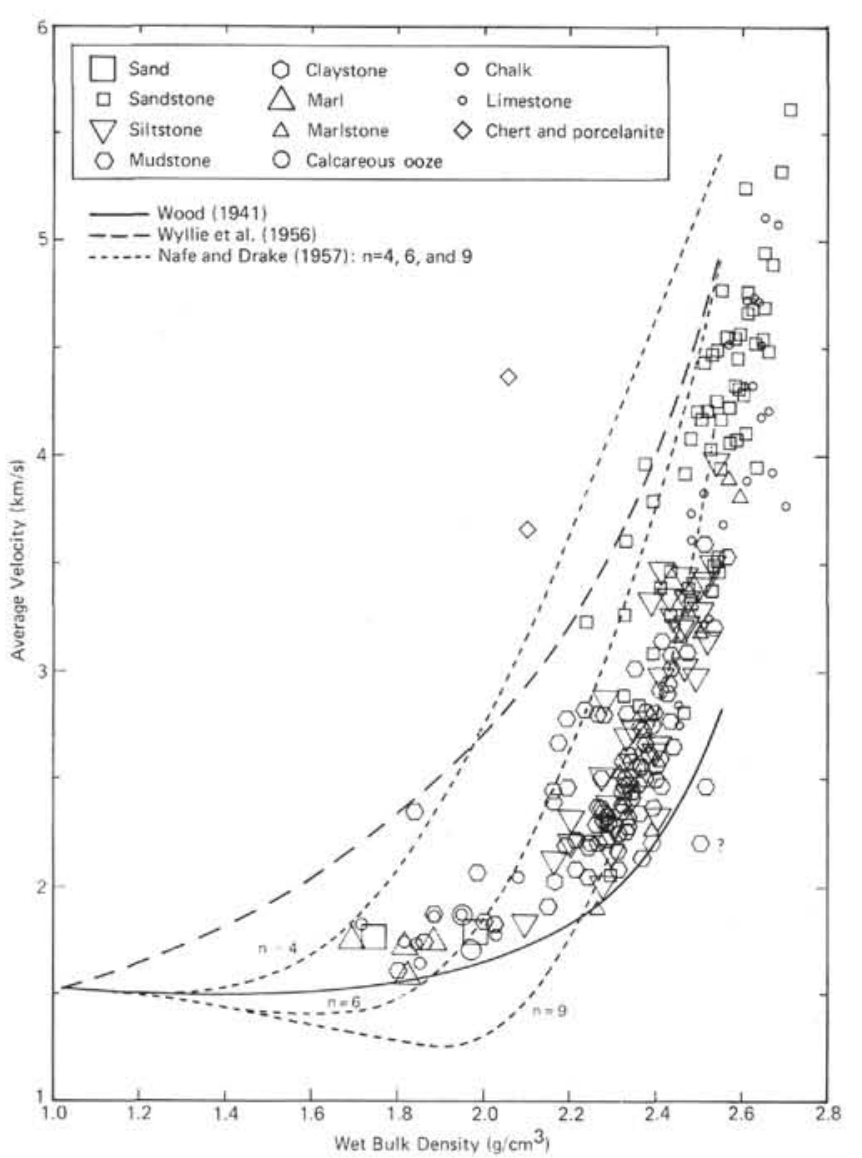

Figure 9. Average of the horizontal and vertical velocity versus wet-bulk density. Included are equations of Wood (1941), Wyllie et al. (1956), and Nafe and Drake (1957), assuming a limestone $\left(2.72 \mathrm{~g} / \mathrm{cm}^{3}, 6.45\right.$ $\mathrm{km} / \mathrm{s})$ matrix with sea water $\left(1.025 \mathrm{~g} / \mathrm{cm}^{3}, 1.53\right.$ $\mathrm{km} / \mathrm{s}$ ) in the pores of the sedimentary rock.

Direct comparison, by plotting of the laboratory velocity and wet-bulk-density data versus depth with the Schlumberger logging data, discloses that although they do not exactly coincide for all cores, the laboratory data and well-log data correspond fairly well. This is so, especially in view of (1) the larger volume measured in the logging, and the small number and size of laboratory samples; (2) the coring and logging depths may not be identical; and (3) the logging tools may be oscillating vertically as the ship leaves. Laboratory densities and velocities, from Core 415-3, were almost identical with those of the logs (e.g., densities of about $1.8 \mathrm{~g} / \mathrm{cm}^{3}$ and velocities of about $1.7 \mathrm{~km} / \mathrm{s}$ ). However, comparisons of the laboratory data from Core 415-4 with the logging data are not close. At the depth of Core 415-4, the density logs have a range of 1.6 to $2.2 \mathrm{~g} / \mathrm{cm}^{3}$ and laboratory densities from Core $415-4$ are about 1.7 to $1.95 \mathrm{~g} / \mathrm{cm}^{3}$. The velocities shown on the logs are 1.6 to $2.1 \mathrm{~km} / \mathrm{s}$, while laboratory velocities, from Core $415-4$, are about 1.8 to $1.95 \mathrm{~km} / \mathrm{s}$.

To develop further statistical comparisons between logging and laboratory data, cross plots of vertical ve-

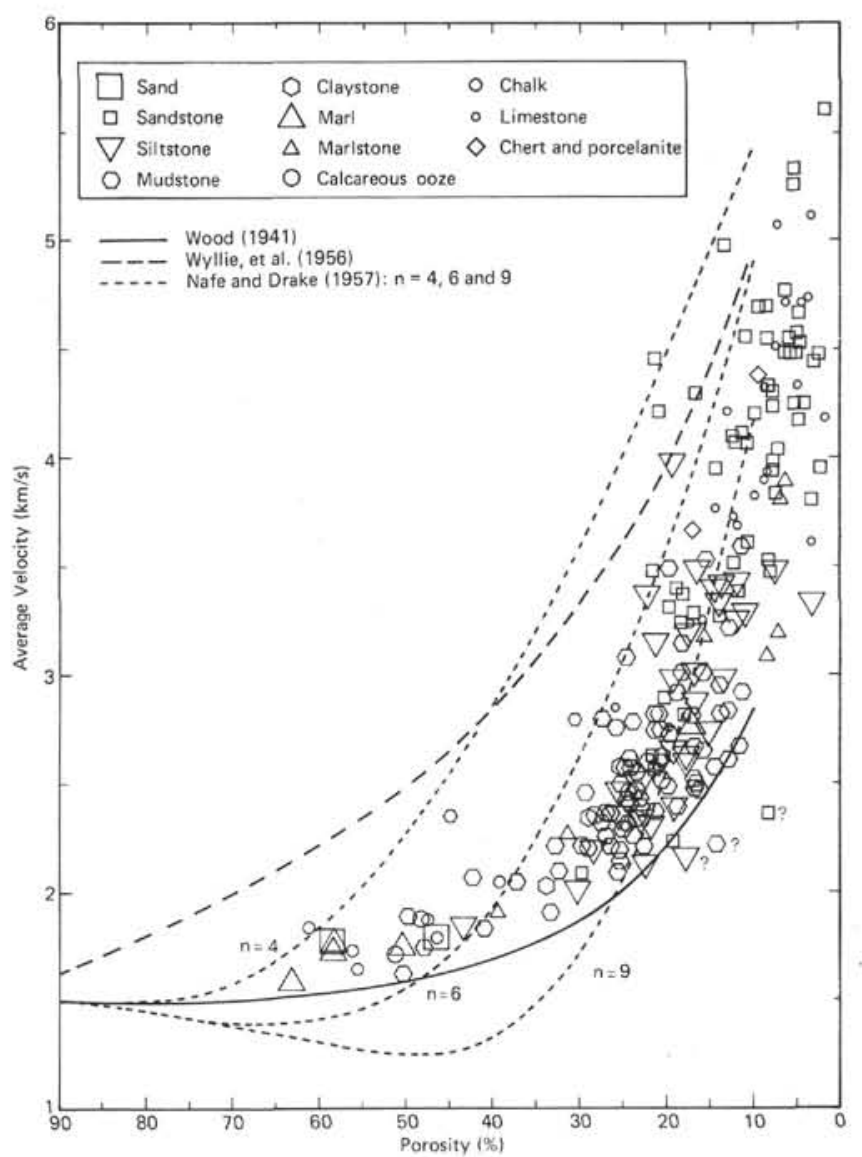

Figure 10. Average of the horizontal and vertical velocity versus porosity. Included are equations of Wood (1941), Wyllie et al. (1957), and Nafe and Drake (1957), assuming and limestone matrix $\left(2.72 \mathrm{~g} / \mathrm{cm}^{3}\right.$, $6.45 \mathrm{~km} / \mathrm{s})$ with sea water $\left(1.025 \mathrm{~g} / \mathrm{cm}^{3}, 1.53 \mathrm{~km} / \mathrm{s}\right)$ in the pores of the sedimentary rock.

locity versus wet-bulk density (Figure 12) of the logging data and laboratory data were made. The velocity and wet-bulk-density values were selected at 10 -meter intervals on the Schlumberger logs from 113 to 273 meters below the sea floor. In order to accurately study the porosity-rebound differences, we should recalculate the in situ velocities to $26^{\circ} \mathrm{C}$ and $1 \mathrm{~atm}$ pressure. However, for the logging data at Site 415, these corrections would be less than 1 per cent of the velocity values, so we have omitted this correction. The scatter diagram contains laboratory values at ambient temperatures (about $26^{\circ} \mathrm{C}$ ) and 1 atm pressure, and well-log data at in situ conditions. The basic contrasts of well-log velocity/density versus laboratory velocity/density data will be related primarily to porosity rebound and, perhaps, slightly to rigidity of the grain-to-grain overburden pressure. However, these rigidity-overburden effects should be small for high-porosity sediments (Hamilton, 1965).

In Figure 12 the laboratory cores appear to show statistically lower densities of about $0.1 \mathrm{~g} / \mathrm{cm}^{3}$ (equivalent to about 5 porosity units) than the in situ logs, as predicted by Hamilton's $(1959,1964,1965,1976)$ consoli- 


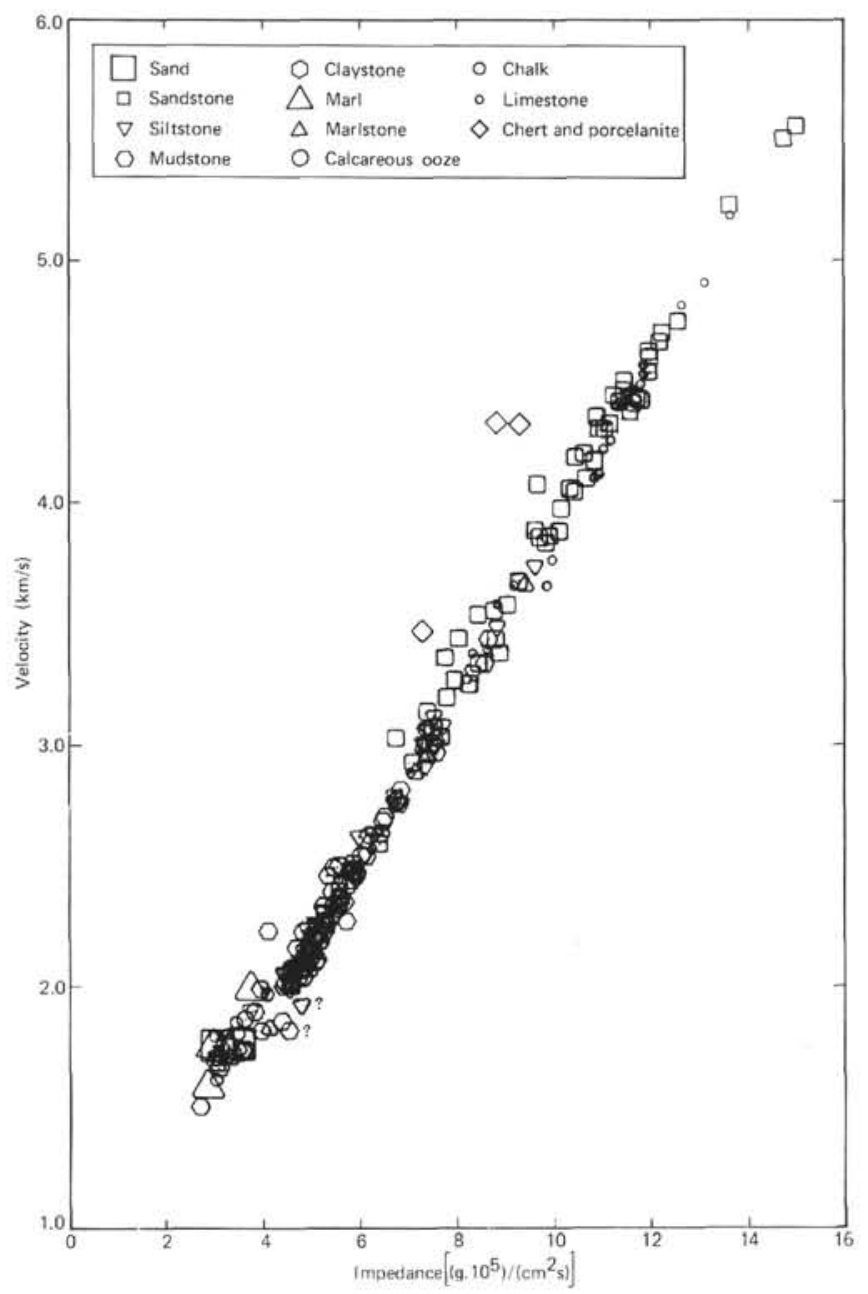

Figure 11. Laboratory-determined vertical velocity versus acoustic impedance, from Sites 415 and 416.

dation rebound curves. Hamilton's (1976) data show a rebound of about 2 to 5 per cent in porosity to be expected from uncemented (30-60\% porosity) sediments as the overburden pressure is released for samples from 113 to 273 meters beneath the sea floor. Future testing at other sites is needed to ensure that the same lithologies are being studied and that the velocity logs are not actually biased on the low side. The sonic log has a shallow depth of investigation and it could be measuring velocities of drill-disturbed formation or drilling muds.

\section{IN SITU VELOCITY}

\section{Corrections to Laboratory Velocities}

As discussed by Hamilton (1965), in order to calculate in situ from laboratory velocities we must correct for: (1) rigidity created by grain-to-grain overburden pressure, (2) hydrostatic pressure and temperature, and (3) porosity rebound as the overburden pressure is released.

The first of these corrections will be insignificant for high-pososity sediment (Hamilton, 1965). However, after the sediment consolidates some amount, perhaps up to 30 per cent porosity, an overburden pressure-rigidity correction becomes important, whose quantity however is unknown. Therefore, Leg 50 data will not be corrected for rigidity created by overburden pressure; thus, in situ velocities corrected from laboratory data will be too small.

The in situ temperature and hydrostatic-pressure correction can be done most effectively using the Boyce (1976b) equation, listed in Table 2. For simplicity, we will assume a calcite-and-seawater system. At laboratory conditions, the limestone matrix has a Voigt-Reuss average velocity of $6.45 \mathrm{~km} / \mathrm{s}\left(2.72 \mathrm{~g} / \mathrm{cm}^{3}\right.$ density $)$ (Christensen, 1965) and 35 per mill seawater has a velocity of $1.53 \mathrm{~km} / \mathrm{s}\left(1.025 \mathrm{~g} / \mathrm{cm}^{3}\right.$ density) ("Table of Sound Speed In Seawater," U. S. Naval Oceanographic Office, Special Publication 58; Press, 1966).

A porosity rebound of 5 per cent ( 5 porosity units) will be assumed for porosities greater than 30 per cent. Naturally, the porosity rebound will decrease from 5 per cent at about 300 meters below the sea floor to zero at the sea floor (Hamilton, 1976). However, the velocity/ porosity relationship of sediments with high porosities and low velocities is not unique or precise, and a large change in porosity will have only a relatively small change in velocity. Therefore, the error of the 5 per cent porosity will have a relatively small effect on the velocity. Between 20 and 30 per cent porosity, a 2.5 per cent porosity (absolute porosity units) rebound will be assumed, and between 0 and 20 per cent porosity, a zero porosity rebound will be assumed.

Porosity corrections to sound velocity may be estimated using scatter diagrams of vertical velocity versus porosity. The measured velocity/porosity plotted point is migrated to the in situ porosity value (and porositycorrected velocity), in a direction approximately parallel to lines representing the velocity/porosity relationships of the Wood (1941) equation and the Wyllie at al. (1956) equation.

In situ calculated velocities for Leg 50 will have undergone (1) the above porosity correction, followed by (2) the hydrostatic-pressure and temperature corrections.

\section{Interval-Velocity Calculations}

At Sites 415 and 416 interval velocities are estimated. They are only rough estimates, because of the heterogeneity of lithology and the thin, alternating sequences. For each characteristic stratigraphic interval it was necessary to estimate percentages of a given lithology and the average velocities for the interval. The latter were corrected to the in situ condition, which includes corrections for porosity rebound, salinity of interstitial water, hydrostatic pressure, and temperatures. These corrections are minimal, as no adjustment is made for the effect of overburden pressure on grain-to-grain rigidity. A temperature gradient of $+3.0^{\circ} \mathrm{C}$ per 100 meters below the sea floor was assumed (based on the temperature log at Site 416), and the surface temperature was estimated at $3.0^{\circ} \mathrm{C}$ (based on the temperature log at Site 416 and 
TABLE 4

Electrical Resistivity, Formation Factors, and Sound-Velocity Data From the Well Logs and $\mathrm{Other}$ Associated Data, Site 416

\begin{tabular}{|c|c|c|c|c|c|c|c|}
\hline $\begin{array}{l}\text { Depth Below a } \\
\text { Sea Level } \\
\text { (m) }\end{array}$ & $\begin{array}{c}\text { Temperature } \\
\left({ }^{\circ} \mathrm{C}\right)\end{array}$ & $\begin{array}{c}\text { Interstitial }^{\mathrm{b}} \\
\text { Water } \\
\text { Salinity } \\
(\% \circ)\end{array}$ & $\begin{array}{c}\text { Hydrostatic } \\
\text { Pressure } \\
\left(\mathrm{kg} / \mathrm{cm}^{2}\right)\end{array}$ & $\begin{array}{l}\text { Electrical }^{\mathrm{d}} \\
\text { Resistivity } \\
\text { of Interstitial } \\
\text { Water, } R_{w} \\
\text { (ohm-m) }\end{array}$ & $\begin{array}{l}\text { Formation } \\
\text { Resistivity, } R_{O} \\
\quad(\text { ohm-m) }\end{array}$ & $\begin{array}{l}\text { Formation } \\
\text { Factor } \\
R_{O} / R_{W}\end{array}$ & $\begin{array}{c}\text { BHC } \\
\text { Sonic } \\
\text { Velocity } \\
(\mathrm{km} / \mathrm{s})\end{array}$ \\
\hline 4300 & 5.9 & 36.9 & 445 & 0.263 & 1.01 & 3.84 & 1.63 \\
\hline 4310 & 6.2 & 37.1 & 446 & 0.260 & 1.03 & 3.96 & 1.76 \\
\hline 4320 & 6.5 & 37.3 & 447 & 0.257 & 1.00 & 3.89 & 1.71 \\
\hline 4330 & 6.8 & 37.4 & 448 & 0.254 & 1.01 & 3.98 & 1.83 \\
\hline 4340 & 7.1 & 37.6 & 449 & 0.250 & 0.86 & 3.44 & 1.56 \\
\hline 4350 & 7.4 & 37.7 & 450 & 0.248 & 0.95 & 3.83 & 1.79 \\
\hline 4360 & 7.7 & 37.8 & 451 & 0.246 & 0.96 & 3.90 & 1.68 \\
\hline 4370 & 8.0 & 37.9 & 452 & 0.243 & 0.94 & 3.87 & 1.67 \\
\hline 4380 & 8.3 & 37.9 & 453 & 0.242 & 1.02 & 4.21 & 1.79 \\
\hline 4390 & 8.6 & 38.0 & 454 & 0.239 & 1.03 & 4.31 & 1.74 \\
\hline 4400 & 8.9 & 38.0 & 455 & 0.237 & 0.95 & 4.01 & 1.67 \\
\hline 4410 & 9.2 & 38.1 & 456 & 0.235 & 0.69 & 2.94 & 1.60 \\
\hline 4420 & 9.5 & 38.2 & 457 & 0.234 & 0.91 & 3.89 & 1.69 \\
\hline 4430 & 9.8 & 38.2 & 459 & 0.232 & 0.90 & 3.88 & 1.67 \\
\hline 4440 & 10.1 & 38.3 & 460 & 0.230 & 0.98 & 4.26 & 1.76 \\
\hline 4450 & 10.4 & 38.3 & 461 & 0.228 & 0.90 & 3.95 & 1.68 \\
\hline 4460 & 10.7 & 38.4 & 462 & 0.227 & 0.80 & 3.52 & 1.76 \\
\hline 4470 & 11.0 & 38.4 & 463 & 0.225 & 0.70 & 3.11 & 1.77 \\
\hline 4480 & 11.3 & 38.5 & 464 & 0.223 & 1.00 & 4.48 & 1.85 \\
\hline 4490 & 11.6 & 38.5 & 465 & 0.222 & 1.01 & 4,55 & 2.03 \\
\hline 4500 & 11.9 & 38.6 & 466 & 0.220 & 1.02 & 4.64 & 1.76 \\
\hline 4510 & 12.2 & 38.7 & 467 & 0.217 & 0.95 & 4.38 & 1.60 \\
\hline 4520 & 12.5 & 38.9 & 468 & 0.215 & 1.00 & 4.65 & 1.73 \\
\hline 4530 & 12.8 & 39.1 & 469 & 0.212 & 1.01 & 4.76 & 1.74 \\
\hline 4540 & 13.1 & 39.2 & 470 & 0.210 & 1.01 & 4.81 & 1.72 \\
\hline 4550 & 13.4 & 39.4 & 471 & 0.208 & 1.01 & 4.86 & 1.76 \\
\hline 4560 & 13.7 & 39.6 & 472 & 0.206 & 1.01 & 4.90 & 1.93 \\
\hline 4570 & 14.0 & 39.7 & 473 & 0.204 & 0.88 & 4.31 & 1.74 \\
\hline 4580 & 14.3 & 39.9 & 474 & 0.202 & 1.02 & 5.05 & 1.68 \\
\hline 4590 & 14.6 & 40.0 & 475 & 0.200 & 1.01 & 5.05 & 1.74 \\
\hline 4600 & 14.9 & 40.2 & 476 & 0.198 & 1.01 & 5.10 & 1.82 \\
\hline 4610 & 15.2 & 40.3 & 477 & 0.196 & 1.01 & 5.15 & 1.85 \\
\hline 4620 & 15.5 & 40.5 & 478 & 0.194 & 1.04 & 5.36 & 1.78 \\
\hline 4630 & 15.8 & 40.7 & 479 & 0.192 & 2.03 & 10.57 & 1.94 \\
\hline 4640 & 16.1 & 40.9 & 480 & 0.190 & 1.01 & 5.32 & 1.67 \\
\hline
\end{tabular}

a Temperature of sea floor assumed to be $3.0^{\circ} \mathrm{C}$ based on Warren (1966), and High Resolution Temperature Log at Site 416. Water Depth $=4193$ meters.

b Salinity of interstitial water from linear interpolation between shipboard determinations. Sea floor is assumed to be $35 \%$ based on Fairbridge et al. (1966).

The hydrostatic pressure was calculated as $=($ depth below sea level $) \times\left(1.035 \mathrm{~g} / \mathrm{cm}^{3}\right)$.

${ }^{d}$ Electrical resistivity was calculated from the temperature and salinity based on Thomas et al. (1934) and the corrected for hydrostatic pressure by Horne and Frysinger (1963) techniques.

Warren, 1966). Tables 5 and 6 give the interstitial-salinity assumptions, percentages of different lithologies and their average velocities, the correction of laboratory velocities to in situ values, and theoretical reflection times.

At Site 415 , the calculated in situ interval velocities for the Tertiary and Cretaceous sections are $2.0 \mathrm{~km} / \mathrm{s}$ (or $1.82 \mathrm{~km} / \mathrm{s}$ if data from Cores $1 \mathrm{~A}$ and $4 \mathrm{~A}$ are not considered characteristic of the in situ geologic section) and $2.08 \mathrm{~km} / \mathrm{s}$, respectively.

The geologic section at Site 416 is divided into seven layers with characteristic physical properties, based on logging and all other available data (see site chapter, this volume). These layers and their estimated in situ interval velocities are as follows:
1. The upper Miocene, Pliocene, and Pleistocene nannofossil marls and oozes, from 0 to 100 meters, with an interval velocity of $1.57 \mathrm{~km} / \mathrm{s}$. The 100 -meter boundary and velocity value are poorly resolved, as the samples were very disturbed by the coring operation.

2. The Eocene, Oligocene, lower and middle Miocene sandstone, siltstone, mudstone, and minor porcellanite, from 100 to 457 meters. Interbedded diatom-rich nannofossil marl and ooze occur in the Oligocene-Miocene section. This layer has an interval velocity of 1.69 $\mathrm{km} / \mathrm{s}$.

3. The lower and middle Eocene mudstone, siltstone, sandstone and rare porcellanite, from 457 to 642 meters, have an interval velocity of $2.26 \mathrm{~km} / \mathrm{s}$. 


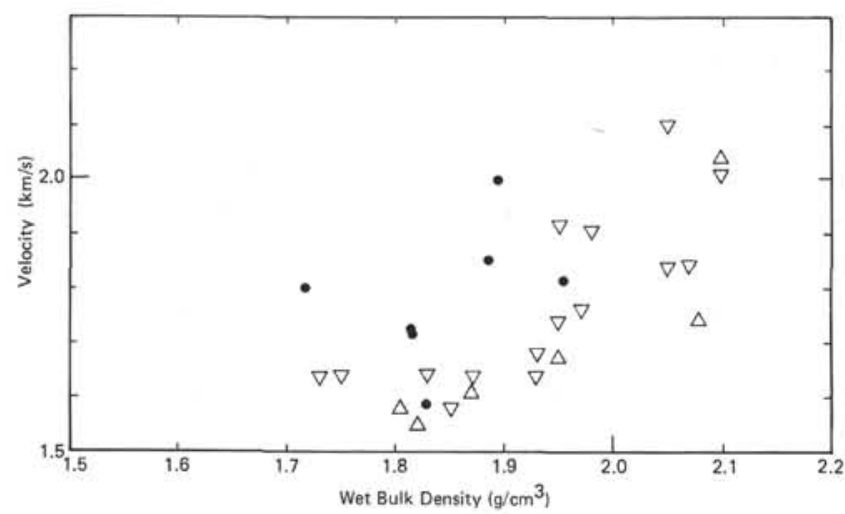

Figure 12. Vertical velocity versus wet-bulk density. The solid dots are the laboratory data; the open triangles pointing upward are the logging data near the cored intervals, and triangles pointing downward are the logging data at 10-meter intervals. The laboratory data (solid dots) show a lesser density ( $\sim 5$ porosity units) than the in situ data (from logs, triangles).

4. The lower Eocene nannofossil marlstone from 642 to 661 meters has an interval velocity of $1.68 \mathrm{~km} / \mathrm{s}$.

5. The lower Aptian to lower Eocene claystone with some limestone, sandstone, and siltstone, from 661 to 880 meters, has an interval velocity of $1.93 \mathrm{~km} / \mathrm{s}$.

6. Valanginian to lower Aptian sandstone, siltstone, and mudstone, from 880 to 1430 meters, have an integrated velocity of $2.61 \mathrm{~km} / \mathrm{s}$.

7. Tithonian to Valanginian sandstone, siltstone, marlstone, and limestone, from 1430 to 1624 meters, have an interval velocity of $3.75 \mathrm{~km} / \mathrm{s}$.

\section{CONCLUSIONS}

1. At Site 415 the electrical formation factor relationship with porosity, for Miocene hemipelagic nannofossil marl and chalk from 113 to 273 meters below the sea floor, agrees with equations developed by the following, in decreasing order of agreement: Boyce (1968), Archie (1942), Kermabon et al. (1969), Winsauer et al. (1952), and Maxwell (1904).

2. The velocity/porosity relationship from logging and laboratory data of Miocene nannofossil marl and chalk, from depths of 113 to 273 meters below the sea floor, indicates that the porosities of the laboratory samples are about 5 per cent greater than for in situ materials. This agrees with the prediction by Hamilton (1976) regarding the effect of overburden pressure.

3. Acoustic anisotropy generally increases with age and depth below the sea floor. It is 0 to 11 per cent in Cenozoic hemipelagic sediments from 0 to 661 meters below the sea floor and 0 to 30 per cent in mainly Cretaceous to Tithonian sandstone-siltstone turbidites in mudstone and minor limestone from 661 to 1624 meters below the sea floor. Between 2.0(?) and 4.2(?) km/s, anisotropy becomes particularly significant, where the anisotropy is about $+0.4 \mathrm{~km} / \mathrm{s}$, or greater. The mudstone, softer sandstones, and softer siltstones tend to have velocities around 2.0 to $2.5 \mathrm{~km} / \mathrm{s}$; the cemented sandstone and limestone cluster about 2.5 to $4.2 \mathrm{~km} / \mathrm{s}$; thus the relative percentage anisotropy is greater for the lower-velocity lithologies. Above $4.2(?) \mathrm{km} / \mathrm{s}$, the wellcemented limestone and sandstone tend to have a smaller $(<0.4 \mathrm{~km} / \mathrm{s})$ absolute anisotropy, and many samples are nearly isotropic. The anisotropy can be related to some combination of the following: (a) elongated or platy grains, which provide a faster path horizontally owing to fewer gaps between minerals, (b) preferred orientation of minerals which have an acoustic anisotropy, (c) cementation along certain horizontal layers, (d) alternating high- and low-velocity layers, and a (e) larger number of horizontal cracks or foliation.

4. The systematic velocity/density diagrams, with horizontal and vertical velocities, should allow better interpretation of combined seismic-refraction, seismic-re-

TABLE 5

Interval Velocity Calculations for Site 415

\begin{tabular}{|c|c|c|c|c|c|c|c|c|c|c|c|c|c|}
\hline $\begin{array}{l}\text { Depth Below } \\
\text { Sea Floor } \\
\text { (m) }\end{array}$ & $\begin{array}{l}\text { Hydrostatic } \\
\text { Pressure } \\
\left(\mathrm{kg} / \mathrm{cm}^{2}\right)\end{array}$ & $\begin{array}{l}\text { Tempera- } \\
\text { tureb } \\
\left.{ }^{\circ} \mathrm{C}\right)\end{array}$ & $\begin{array}{c}\text { Estimated } \\
\text { Salinity of } \\
\text { Interstitial } \\
\text { Water } \\
(\%)\end{array}$ & $\begin{array}{c}\text { Interstitial } \\
\text { Water Velocity } \\
\text { at } 26^{\circ} \mathrm{C} \text { and One } \\
\text { Atmospheric } \\
\text { Pressure } \\
(\mathrm{km} / \mathrm{s})\end{array}$ & $\begin{array}{l}\text { Interstitial }{ }^{\mathrm{d}} \\
\text { Water In Situ } \\
\text { Velocity } \\
(\mathrm{km} / \mathrm{s})\end{array}$ & $\begin{array}{l}\text { Specific } \\
\text { Interval } \\
\text { Velocity of } \\
\text { Interstitial } \\
\text { Water at One } \\
\text { Atmospheric } \\
\text { Pressured } \\
\text { and } 26^{\circ} \mathrm{C} \\
(\mathrm{km} / \mathrm{s})\end{array}$ & $\begin{array}{c}\text { Speciffic } \\
\text { Interval } \\
\text { Velocity of } \\
\text { Interstitial } \\
\text { Water } \\
\text { In Situ } \\
(\mathrm{km} / \mathrm{s})\end{array}$ & $\begin{array}{c}\text { Specific } \\
\text { Interval } \\
\text { Velocity of } \\
\text { Formation a } \\
\text { Laboratory } \\
\text { Conditions } \\
\text { (km/s) }\end{array}$ & $\begin{array}{cc} & \text { Estimated } \\
& \text { Porosity } \\
& \text { Rebound } \\
\text { of } & \text { of Sample } \\
\text { at } & \text { Removed } \\
\text { y } & \text { From } \\
\text { e } & \text { In Situ } \\
& \text { (\%) }\end{array}$ & $\begin{array}{ll}\text { ed } & \\
\text { y } \\
\text { hd } & \text { Laboratory } \\
\text { le } & \text { Velocity } \\
\text { ed } & \text { Adjusted for } \\
\text { Porosity } \\
\text { Rebound } \\
(\mathrm{km} / \mathrm{s})\end{array}$ & $\begin{array}{c}\text { Porosity } \\
\text { Corrected } \\
\text { Velocity } \\
\text { Adjusted } \\
\text { to In Situd } \\
\text { Hydrostatic } \\
\text { Pressure and } \\
\text { Temperature } \\
(\mathrm{km} / \mathrm{s})\end{array}$ & $\begin{array}{l}\text { Specific } \\
\text { Interval } \\
(\mathrm{m})\end{array}$ & $\begin{array}{l}\text { Reflection } \\
\text { Time } \\
\text { Round } \\
\text { Tripe } \\
\text { (s) }\end{array}$ \\
\hline 0 & 290.5 & 3.0 & 35.2 & 1.537 & 1.510 & & & & & 20001800 & & & - \\
\hline 509 & 343 & 18.3 & 60.0 & 1.562 & 1.596 & $\begin{array}{l}1.550 \\
1.553\end{array}$ & $\begin{array}{l}1.553 \\
1.612\end{array}$ & $1.99 \mathrm{~g}$ & $\begin{array}{l}5.0 \% \text { mud- } \\
\text { stone }\end{array}$ & $\begin{array}{l}2.00(1.82)^{\circ} \\
2.03^{\mathrm{g}}\end{array}$ & $\begin{array}{l}2.00(1.82)^{\circ} \\
2.08^{\mathrm{g}}\end{array}$ & 525 & $0.509(0.559)^{f}$ \\
\hline 1034 & 398 & 34.0 & 42.0 & 1.544 & 1.628 & - & - & - & $\begin{array}{l}0.0 \% \text { lime- } \\
\text { stone }\end{array}$ & - & - & - & $1.014(1.064)^{f}$ \\
\hline
\end{tabular}

a Hydrostatic pressure $=($ depth below sea level $) \times\left(1.035 \mathrm{~g} / \mathrm{cm}^{3}\right)$.

b Temperature is based on $3.0^{\circ} \mathrm{C}$ sea floor temperature and $+3.0^{\circ} \mathrm{C} / 100 \mathrm{~km}$ temperature gradient from temperature log at Site 416 and Warren (1966),

cSalinity of interstitial water from linear interpolations between shipboard determinations. Sea floor salinity is assumed to be $35.0 \%$ based on Fairbridge et al, (1966).

dIn situ interstitial water velocity and laboratory velocities are adjusted for hydrostatic pressure and temperature using, "Tables of Sound Speed in Sea Water," U. S. Naval Oceanographic Office, Special Publication 58. Laboratory sample velocities were processed through the Boyce (1976b) equation in Table 2 .

lication 58. Laboratory sample velocities were processed through the Boyce $(1976 \mathrm{~b})$ equation in Table 2 .
eaboratory velocities do not include an adjustment for overburden pressure effects, thus the velocities are minimal and the reflection times are probably too long.

The interval from 0 to 509 meters assumes: An average laboratory velocity of $1.93 \mathrm{~km} / \mathrm{s}$ or $1.72 \mathrm{~km} / \mathrm{s}$ depending on which of the following assumptions is accepted. $1.93 \mathrm{~km} / \mathrm{s}$ is the average laboratory veloc.

The interval from 0 to 509 meters assumes: An average laboratory velocity of $1.93 \mathrm{~km} / \mathrm{s}$ or $1.72 \mathrm{~km} / \mathrm{s} \mathrm{depending} \mathrm{on} \mathrm{which} \mathrm{of} \mathrm{the} \mathrm{following} \mathrm{assumptions} \mathrm{is} \mathrm{accepted.} 1.93 \mathrm{~km} / \mathrm{s}$ is the average laboratory veloc.
ity if one assumes (1) a $1.51 \mathrm{~km} / \mathrm{s}$ sea floor velocity; (2) that the samples in Cores $1 \mathrm{~A}$ and $4 \mathrm{~A}$ are representative of the in situ geologic section, and not the most drill-resistant rocks surviving the coring operaity if one assumes (1) a $1.51 \mathrm{~km} / \mathrm{s}$ sea floor velocity; (2) that the samples in Cores $1 \mathrm{~A}$ and $4 \mathrm{~A}$ are representative of the in situ geologic section, and not the most drill-resistant rocks surviving the coring opera-
tions, and (3) in averaging each core, that the data from Cores $4 \mathrm{~A}, 5 \mathrm{~A}$, and $6 \mathrm{~A}$ were treated as a single core. To the contrary, if one assumes that Cores $1 \mathrm{~A}$ and $4 \mathrm{~A}$ are not representative of the in-situ geologic section, and therefore deletes the data from these cores, then the calculated interval (laboratory conditions) velocity is $1.72 \mathrm{~km} / \mathrm{s}$. All velocities and reflection times in parentheses in the above assume logic section, and therefore deletes the data from these
$1.72 \mathrm{~km} / \mathrm{s}$ is the interval velocity (at lab conditions).

gFor the interval from 509 to 1034 meters we assume: (1) At laboratory ambient temperature and pressure, the average velocity $=(90 \%$ mudstone @ $1.856 \mathrm{~km} / \mathrm{s})+(10 \%$ limestone @ $3.204 \mathrm{~km} / \mathrm{s})=1.99 \mathrm{~km} / \mathrm{s}$.

(2) Average lab velocity corrected for porosity rebound, the average velocity $=(90 \%$ mudstone @ $1.900 \mathrm{~km} / \mathrm{s})+(10 \%$ limestone $@ 3.204 \mathrm{~km} / \mathrm{s})=2.03 \mathrm{~km} / \mathrm{s}$. $(3)$ Average velocity adjusted for porosity, tem-
(2) 3 . perature, and hydrostatic pressure $=(90 \%$ mudstone@ @ $1.955 \mathrm{~km} / \mathrm{s})+(10 \%$ limestone @ $3.240 \mathrm{~km} / \mathrm{s})=2.08 \mathrm{~km} / \mathrm{s}$. 
TABLE 6

Interval Velocity Calculations, Site 416

\begin{tabular}{|c|c|c|c|c|c|c|c|c|c|c|c|c|c|c|}
\hline $\begin{array}{l}\text { Depth Belowa } \\
\text { Sea Floot } \\
\text { (m) }\end{array}$ & $\begin{array}{c}\text { Hydrostatic }{ }^{\mathrm{a}} \\
\text { Pressure } \\
\left(\mathrm{kg} / \mathrm{cm}^{2}\right)\end{array}$ & $\begin{array}{c}\text { Tempera- } \\
\text { tureb } \\
(\mathrm{C})\end{array}$ & $\begin{array}{c}\text { Estimatedc } \\
\text { Salinity of } \\
\text { Interstitial } \\
\text { Water } \\
(\%)\end{array}$ & $\begin{array}{c}\text { Interstitiald } \\
\text { Water Velocity } \\
\text { At } 26^{\circ} \mathrm{C} \text { and One } \\
\text { Atmospheric } \\
\text { Pressure } \\
(\mathrm{km} / \mathrm{s})\end{array}$ & $\begin{array}{l}\text { Interstitial }{ }^{d} \\
\text { Water In Situ } \\
\text { Velocity } \\
(\mathrm{km} / \mathrm{s})\end{array}$ & $\begin{array}{l}\text { Specific } \\
\text { Interval } \\
\text { Velocity of } \\
\text { Interstitial } \\
\text { Water at One } \\
\text { Atmospheric } \\
\text { Pressure } \\
\text { and } 26^{\circ} \mathrm{C} \\
(\mathrm{km} / \mathrm{s})\end{array}$ & $\begin{array}{l}\text { Specific } \\
\text { Interval } \\
\text { Velocity of } \\
\text { Interstitial } \\
\text { Water } \\
\text { In Situd } \\
\text { (km/s) }\end{array}$ & $\begin{array}{l}\text { Specific } \\
\text { Interval } \\
\text { Velocity of } \\
\text { Formation at } \\
\text { Laboratory } \\
\text { Conditions } \\
(\mathrm{km} / \mathrm{s})\end{array}$ & $\begin{array}{c}\text { Estimated } \\
\text { Porosity } \\
\text { Reboundh } \\
\text { of Sample } \\
\text { Removed } \\
\text { From } \\
\text { In Situ } \\
(\%)\end{array}$ & $\begin{array}{l}\text { Laboratory } \\
\text { Velocity } \\
\text { Adjusted for } \\
\text { Porosity } \\
\text { Rebound } \\
(\mathrm{km} / \mathrm{s})\end{array}$ & $\begin{array}{l}\text { Porosity } \\
\text { Corrected } \\
\text { Velocity }^{\mathrm{e}} \\
\text { Adjusted } \\
\text { to In Situd } \\
\text { Hydrostatic } \\
\text { Pressure and } \\
\text { Temperature } \\
(\mathrm{km} / \mathrm{s})\end{array}$ & $\begin{array}{l}\text { Velocity } \\
\text { From } \\
\text { Well } \\
\text { Logsf } \\
(\mathrm{km} / \mathrm{s})\end{array}$ & $\begin{array}{c}\text { Specific } \\
\text { Interval } \\
\text { (m) }\end{array}$ & $\begin{array}{c}\text { Reflection } \\
\text { Time } \\
\text { Round } \\
\text { Tripe } \\
\text { (s) }\end{array}$ \\
\hline 0 & 436 & 3.0 & 35.0 & & 1.535 & & & & & & & $1.568^{\mathrm{g}}$ & 100 & \\
\hline 100 & & & & & & & & & & & & 1.69 & 357 & 0.128 \\
\hline 457 & & & & & & & & & & & & 2.26 & 185 & 0.550 \\
\hline 642 & & & & & & & & & & & & 1.68 & 19 & 0.714 \\
\hline \multirow[t]{2}{*}{661} & \multirow[t]{2}{*}{504} & \multirow[t]{2}{*}{22.8} & \multirow[t]{2}{*}{49.0} & \multirow[t]{2}{*}{1.552} & \multirow[t]{2}{*}{1.626} & & & & & & & 1.00 & 17 & 0.737 \\
\hline & & & & & & 1.558 & 1.648 & $1.79^{i}$ & $\begin{array}{l}5 \% \text { mud- } \\
\text { stone }\end{array}$ & $1.84^{h, i}$ & $1.93^{i}$ & & 219 & \\
\hline 880 & 527 & 29.4 & 59,0 & 1,563 & 1.669 & 1.561 & 1.670 & أj & $\begin{array}{l}5 \% \text { mud- } \\
\text { stone }\end{array}$ & $2.45^{\mathrm{j}, \mathrm{i}}$ & $2.51^{j}$ & & 298 & 0.964 \\
\hline \multirow[t]{2}{*}{1178} & \multirow[t]{2}{*}{558} & \multirow[t]{2}{*}{38.3} & \multirow[t]{2}{*}{55.0} & \multirow[t]{2}{*}{1.559} & \multirow[t]{2}{*}{1.670} & & & & $5 \%$ mud- & & & & & 1.201 \\
\hline & & & & & & 1.559 & 1.672 & $2.56^{k}$ & stone & $2.64^{\mathrm{k}, \mathrm{I}}$ & $2.73^{k}$ & & 252 & 1.386 \\
\hline 1430 & 584 & 45.9 & 55.0 & 1.559 & 1.674 & 1.559 & 1.676 & $3.10^{1}$ & $\begin{array}{l}2.5 \text { mud- } \\
\text { stoneh }\end{array}$ & $3.16^{1, i}$ & $3.25^{1}$ & & 186 & \\
\hline 1616 & 603 & 51.5 & 55.0 & 1.559 & 1.678 & & & & & & & & & \\
\hline
\end{tabular}

${ }^{a}$ Hydrostatic pressure $=($ depth below sea level $) \times\left(1.035 \mathrm{~g} / \mathrm{cm}^{3}\right)$.

${ }^{b}$ Based on $3.0^{\circ} \mathrm{C}$ surface temperature and $+3.0 / 100 \mathrm{~km}$ temperature gradient from temperature log.

${ }^{c}$ Salinity of interstitial water from linear interpolations between shipboard determinations. Sea floor salinity is assumed to be $35 \%$ based on Fairbridge et al. (1966).

$\mathrm{d}$ In situ interstitial water velocity and laboratory velocities are adjusted for hydrostatic pressure and temperature using. "Table of Sound Speed in Sea Water," U. S. Naval Oceanographic Office, Special Publication 58. Laboratory sample velocities were processed through the Boyce (1976b) equation in Table 2.

'Laboratory velocities do not include an adjustment for overburden pressure effects; thus the velocities are minimal values, and the reflection times are probably too long.

fVelocities estimated from actual analog presentation, but not the depth and integrated time, as the latter appeared too low.

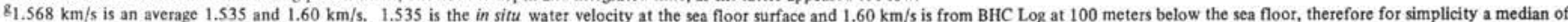
these two values is taken as an approximation of interval in situ velocity between 0 and 100 meters below the sea floor.

hPorosity rebound is assumed to be 5 per cent (absolute porosity units) for sample with $>30$ per cent porosity, 2.5 per cent for samples with $20<30$ per cent porosities, and zero for samples with $<20 \%$ porosity,

The limestones, sandstones, and siltstones below 661 meters depth had $<20$ per cent porosity, therefore they had no porosity-rebound correction.

For the interval from 661 to 880 meters we assume: (1) Average velocity at ambient laboratory temperature and pressure $=(98 \%$ mudstone @ $1.75 \mathrm{~km} / \mathrm{s})+(2 \%$ limestone $@ 3.90 \mathrm{~km} / \mathrm{s})=1.79 \mathrm{~km} / \mathrm{s}$. (2) Average laboratory velocity adjusted for porosity rebound $=(98 \%$ mudstone $(Q 1.80 \mathrm{~km} / \mathrm{s})+(2 \%$ limestone $\Theta 3.90 \mathrm{~km} / \mathrm{s})=1.84 \mathrm{~km} / \mathrm{s}$. (3) Average velocity corrected for porosity, hydrostatic pressure, and temperature $=$ $(98 \%$ mudstone e $1.89 \mathrm{~km} / \mathrm{s})+(2 \%$ limestone $(e .3 .95 \mathrm{~km} / \mathrm{s})=1.93 \mathrm{~km} / \mathrm{s}$.

F For the in terval from 880 to 1178 meters we assume: (1) Average velocity at ambient laboratory temperature and pressure $=(30 \%$ sandstone and siltstone $@ 3.50 \mathrm{~km} / \mathrm{s})+(70 \%$ mudstone @ $1.92 \mathrm{~km} / \mathrm{s})=2.39 \mathrm{~km} / \mathrm{s}$ (2) Average laboratory velocity adjusted for porosity rebound $=(30 \%$ sandstone and siltstone @ $3.50 \mathrm{~km} / \mathrm{s})+(70 \%$ mudstone @ $1.98 \mathrm{~km} / \mathrm{s})=2.42 \mathrm{~km} / \mathrm{s}$. (3) Average velocity corrected for porosity, temperature and hydrostatic pressure $=(30 \%$ sandstone and siltstone $@ 3.55 \mathrm{~km} / \mathrm{s})+(70 \%$ mudstone $\Theta 2.06 \mathrm{~km} / \mathrm{s})=2.51 \mathrm{~km} / \mathrm{s}$

$\mathrm{k} F$ or the interval from 1178 to 1430 meters we assume: (1) Average velocity at ambient laboratory temperature and pressure $=(22 \%$ sandstone and siltstone @ $3.50 \mathrm{~km} / \mathrm{s})+(78 \%$ mudstone @ $2.30 \mathrm{~km} / \mathrm{s})=2.56$ $\mathrm{km} / \mathrm{s}$. (2) Average laboratory velocity adjusted for porosity rebound $=(22 \%$ sandstone and siltstone @ $3.50 \mathrm{~km} / \mathrm{s})+(78 \%$ mudstone $@ 2.40 \mathrm{~km} / \mathrm{s})=2.64 \mathrm{~km} / \mathrm{s}$. $(3)$ Average velocity adjusted for porosity, temperature, and hydrostatic pressure $=(22 \%$ sandstone and siltstone $@ 3.57 \mathrm{~km} / \mathrm{s})+(78 \%$ mudstone $@ 2.49 \mathrm{~km} / \mathrm{s})=2.73 \mathrm{~km} / \mathrm{s}$.

IFor the interval from 1430 to 1616 meters we assume: (1) Average velocity at ambient laboratory temperature and pressures $=(28 \%$ sandstone and siltstone @ $3.41 \mathrm{~km} / \mathrm{s})+(10 \%$ limestone @ 4.19 km/s $)+(3 \%$ marl @ $3.24 \mathrm{~km} / \mathrm{s})+(65 \%$ mudstone $@ 2.50 \mathrm{~km} / \mathrm{s})=3.10 \mathrm{~km} / \mathrm{s}$. (2) Average laboratory velocity adjusted for porosity rebound $=(28 \%$ sandstone and siltstone @ $3.41 \mathrm{~km} / \mathrm{s})+(10 \%$ limestone $@ 4.19 \mathrm{~km} / \mathrm{s})+(3 \%$ marl @ $3.24 \mathrm{~km} / \mathrm{s})+(65 \%$ mudstone @ $2.60 \mathrm{~km} / \mathrm{s})=3.16 \mathrm{~km} / \mathrm{s}$. (3) Average velocity adjusted for porosity, temperature, and hydrostatic pressure $=(28 \%$ sandstone and siltstone @ $3.48 \mathrm{~km} / \mathrm{s})+(10 \%$ limestone (8) $4.24 \mathrm{~km} / \mathrm{s})+(3 \% \mathrm{marl} @ 3.32 \mathrm{~km} / \mathrm{s})+(65 \%$ mudstone $@ 2.69 \mathrm{~km} / \mathrm{s})=3.25 \mathrm{~km} / \mathrm{s}$.

flection, sonobuoy, gravity, and well-log data. Acoustic anisotropy of terrigenous clastics can now be taken into consideration.

\section{ACKNOWLEDGMENTS}

The author thanks Drs. E. L. Hamilton and R. D. Hyndman for reviewing the manuscript.

\section{REFERENCES}

Archie, G. E., 1942. The electrical resistivity log as an aid in determining some reservoir characteristics, Am. Inst. Mining Metall. Pet. Eng. Trans., v. 146, p. 54.

1947. Electrical resistivity an aid in core analysis interpretation, Am. Assoc. Petrol. Geol. Bull., v. 31, p. 350.

Bedcher, A. Z., 1965. Electrical anisotropy of clays - its geological significance, Internat. Geol. Rev., v. 7, p. 7

Berg, J. W., Jr., 1952. Conductivity study of aqueous kaolin $\mathrm{NaCl}$ mixtures, Producers Monthly, v. 16, p. 36.

Birch, F., 1961. The velocity of compressional waves in rocks to 10 kilobars, Part 2, Geophys. Res., v. 66, p. 2199.

Boyce, R. E., 1968. Electrical resistivity of modern marine sediments from the Bering Sea, J. Geophys. Res., v. 73, p. 4759. 1976a. Definitions and laboratory techniques of compressional sound velocity parameters and wet-water content, wet-bulk density, and porosity parameters by gravimetric and gamma ray attenuation technqies. In Schlanger, S. O., Jackson, E. D., et al., Initial Reports of the Deep Sea Drilling Project, v. 33: Washington (U. S. Government Printing Office), p. 931-958. $1976 \mathrm{~b}$. Sound velocity-density parameters of sediment and rock from DSDP drill Sites 315-318 on the Line Islands Chain, Manihiki Plateau, and Tuamotu Ridge in the Pacific Ocean. In Schlanger, S. O., Jackson, E. D., et al., Initial Reports of the Deep Sea Drilling Project, v. 33: Washington (U. S. Government Printing Office), p. 695-728.

Bullen, K. E., 1947. Introduction to the theory of seismology: London (Cambridge University Press).

Christensen, N. I., 1965. Compressional wave velocities in metamorphic rocks at pressures to 10 kilobars, J. Geophys. Res., v. 70, p. 6147.

Couture, R. A., Miller, R. S., and Gieskes, J. M. 1978. Interstitial water and mineralogical studies, Leg 41. In Lancelot, Y., Seibold, E., et al., Initial Reports of the Deep Sea Drilling Project, v. 41: Washington (U. S. Government Printing Office), p. 907-914.

de Witte, L., 1950a. Resistivity and saturation distribution in infiltrated zones of porous formations around drill holes, Oil Gas J., v. 49, p. 246.

, 1950b. Relations between resistivities and fluid contents of porous media, Oil Gas J., v. 49, p. 120.

Evans, H. B., 1965. GRAPE - A device for continuous determination of material density and porosity, SPWIA Logging sympy., 6th Ann., Trans.: Dallas, Texas, v. 2, p. B1.

Fairbridge, R. W., Gordon, A., and Olaussen, E., 1966. Atlantic Ocean. In Fairbridge, R. W. (Ed.), The encyclopedia 
of oceanography: New York (Reinhold Publishing Corp.), v. 1 , p. 56.

Greene, E. S., 1962. Principles of physics: Englewood Cliffs, N. J. (Prentics Hall Inc.).

Hamilton, E. L., 1959. Thickness and consolidation of deep sea sediments, Geol. Soc. Am. Bull., v. 70, p. 1399.

1964. Consolidation characteristics and related properties of sediments from experiental Mohole (Guadalupe site), J. Geophys. Res., v. 69, p. 4257. 1965. Sound speed and related physical properties of sediments from experimental Mohole (Guadalupe site), Geophysics, v. 30, p. 257. 1970. Reflection coefficients and bottom losses at normal incidence computed from Pacific sediment properties, Geophysics, v. 35, p. 995. 1971. Prediction of in situ acoustic and elastic properties of marine sediments, J. Geophys., v. 36, p. 266. 1976. Variations of density and porosity with depth in deep-sea sediments, J. Sediment. Petrol., v. 46, p. 280.

Horne, R. A., 1965. The physical chemistry and structure of sea water, Water Resources Res., Second quarter, v. 1, p. 263.

Horne, R. A. and Courant, R. A., 1964. Application of Walden's rule to the electrical conduction of sea water, $J$. Geophys. Res., v. 69, p. 1971

Horne, R. A. and Frysinger, G. R., 1963. The effect of pressure on the electrical conductivity of sea water, J. Geophys. Res., v. 68, p. 1967.

Howell, B. F., Jr., 1953. Electrical conduction in fluid saturated rocks, Part I, World Oil, v. 136, p. 113.

Keller, G. V., 1951. The role of clays in the electrical conductivity of the Bradford Sand, Producers Monthly, v. 15, p. 23. 1966. Electrical Properties of Rock and Minerals. In Clark, S. P. (Ed.), Handbook of physical constants: New York (Geol. Soc. Amer., Mem. 97), p. 553.

Keller, G. V. and Frischknecht, F. C., 1966. Electrical methods in geophysical prospecting: New York (Pergamon Press).

Kermabon, A., Gehin, C., and Blavier, P., 1969. A deep-sea electrical resistivity probe for measuring porosity and density of unconsolidated sediments, Geophysics, v. 34, p. 554.

Laughton, A. S., 1957. Sound propagation in compacted ocean sediments, Geophysics, v. 22, p. 233.

Maxwell, J. C., 1904. Electricity and magnetism: Oxford (Clarendon Press), v. 1, 3rd ed.

Nafe, J. E. and Drake, C. L., 1957. Variation with depth in shallow and deep water marine sediments of porosity density and the velocities of compressional and shear waves, Geophysics, v. 22, p. 523.
1963. Physical properties of marine sediments. In Hill, M. N. (Ed.), The sea: New York (Interscience), v. 3, p. 749.

Patnode, H. W. and Wyllie, M. R. J., 1950. The presence of conductive solids in reservoir rocks as a factor in electric log interpretation, J. Petrol. Tech., v. 2, p. 42.

Press, F., 1966. Seismic Velocities. In Clarks, S. P. (Ed.), Handbook of physical constants: New York (Geol. Soc. Am. Memoir 97), p. 195.

Schlumberger Ltd., 1972. Log interpretation charts: New York (Schlumberger Ltd.).

Scholl, D. W., 1963. Techniques for removing interstitial water from coarse grained sediments for chemical analyses, Sedimentology, v. 2, p. 156.

Siever, R., Garrels, R. M., Kanwisher, J., and Berner, R. A., 1961. Interstitial waters of Recent marine muds off Cape Bode, Science, v. 134, p. 1071.

Siever, R., Kevin, C. B., and Berner, R. A., 1965. Composition of interstitial waters of modern sediments, J. Geol., v. 73 , p. 39.

Thomas, B. D., Thompson, T. G., and Utterback, C. L., 1934. The electrical conductivity of sea water, Conseil, Internat. Explor. Mer., v. 9, p. 28.

Warren, B., 1966. Oceanography, physical In Fairbridge, R. W. (Ed.), The encyclopedia of oceanography: New York (Reinhold Publishing Corp.), v. 1, p. 56.

Winsauer, W. O. and McCardell, W. M., 1953. Ionic doublelayer conductivity in reservoir rock, $\mathrm{Am}$. Inst. Mining Metall. Petrol. Eng. Trans., v. 198, p. 129.

Winsauer, W. O., Shearin, H. M., Jr., Masson, P. H., and Williams, M., 1952. Resistivity of brine-saturated sands in relations to pore geometry, Am. Assoc. Petrol. Geol. Bull., v. 36 , p. 253.

Wood, A. B., 1941. A Textbook of sound: New York (MacMillan).

Wyllie, M. R. J., 1955. Role of clay in well-long interpretation on clays and clay technology, July, 1952, Cal. Div. Mines Bull., v. 169, p. 282.

Wyllie, M. R. J. and Gregory, A. R., 1953. Formation factors of unconsolidated porous media: influence of particle shape and effect of cementation, J. Petrol. Tech., v. 198, p. 103.

Wyllie, M. R. J. and Southwick, P. F., 1954. An experimental investigation of the S. P. and resistivity phenomena in dirty sands, J. Petrol. Tech., v. 6, p. 44.

Wyllie, M. R. J., Gregory, H. R., and Gardner, L. W., 1956. Elastic waves in heterogeneous and porous media, Geophysics, v. 21, p. 41. 